Article type : Original Manuscript

\title{
Formation and evolution of back-barrier perched lakes in rocky coasts: An example of a Holocene system in north-west Spain
}

\author{
Alberto Sáez ${ }^{1}$, Rafael Carballeira ${ }^{2}$, Juan J. Pueyo ${ }^{3}$, David Vázquez-Loureiro ${ }^{4}$, Manel Leira ${ }^{4,5}$, Armand \\ Hernández $^{4,5}$, Blas L. Valero-Garcés ${ }^{6}$, Roberto Bao ${ }^{4}$
}

${ }^{1}$ Department of Earth and Ocean Dynamics, Faculty of Earth Sciences, Universitat de Barcelona, C. Martí i Franqués s/n, 08028 Barcelona, Spain

${ }^{2}$ Department of Botany, Faculty of Biology, University of Santiago de Compostela, 15782, Santiago de Compostela, Spain

${ }^{3}$ Department of Mineralogy, Petrology and Applied Geology, Faculty of Earth Sciences, Universitat de Barcelona, C. Martí i Franqués s/n, 08028 Barcelona, Spain

${ }^{4}$ Centro de Investigacións Científicas Avanzadas (CICA), Facultade de Ciencias, Universidade da Coruña, 15071 A Coruña, Spain

${ }^{5}$ Faculty of Sciences, Instituto Dom Luiz (IDL), Universidade de Lisboa, 1749-016, Lisbon, Portugal

${ }^{6}$ Pyrenean Institute of Ecology - CSIC, Av. Montañana 1005, 50059 Zaragoza, Spain

Corresponding e-mail: a.saez@ub.edu

Associate Editor - Stéphanie Girardclos

Short Title - Back-barrier perched-lakes in rocky coasts

Keywords: Bedrock topography, coastal lakes, Galicia, high-resolution chronology, Holocene, sealevel changes, sequence stratigraphy.

This is an Accepted Article that has been peer-reviewed and approved for publication in the Sedimentology, but has yet to undergo copy-editing and proof correction. Please cite this article as an "Accepted Article"; doi: 10.1111/sed.12451 This article is protected by copyright. All rights reserved. 


\section{ABSTRACT}

Coastal back-barrier perched lakes are freshwater bodies that are elevated over sea-level and are not directly subjected to the inflow of seawater. This study provides a detailed reconstruction of the Doniños back-barrier perched lake that developed at the end of a small river valley in the rocky coast of the north-west Iberian Peninsula during the Holocene transgression. Its sequence stratigraphy was reconstructed based on a core transect across the system, the analyses of its lithofacies and microfossil assemblages, and a high-resolution radiocarbon-based chronology. The Doniños perched lake was formed ca $4.5 \mathrm{ka} \mathrm{BP}$. The setting of the perched lake was favoured by Late Holocene sealevel stabilization and the formation of a barrier and back-barrier basin, which was contemporaneous with the high systems tract period. This basin developed over marine and lagoonal sediments deposited between 10.2 and $8.0 \mathrm{ka} \mathrm{BP}$, during rapidly rising sea-level characteristic of the transgressive systems track period. At $1.1 \mathrm{ka} \mathrm{BP}$, the barrier was breached and the perched lake was partially emptied, causing the erosion of the back-barrier basin sediments and a significant sedimentary hiatus. Both enhanced storminess and human intervention were likely to be responsible for this event. After $1 \mathrm{ka} \mathrm{BP}$, the barrier reclosed and the present-day lake was reformed, with the water level reaching as high as $5 \mathrm{~m}$ above mean sea-level. The depositional evolution of the Doniños system serves as a model of coastal back-barrier perched lakes in coastal clastic systems that have developed over gently seaward-dipping rugged substrates at small distances from the shoreline and under conditions of rising sea-level and high sediment supply. A review of estuaries, back-barrier lagoons, pocket beaches and back-barrier perched lakes in the rocky coast of north-west Spain shows that the elevation of the bedrock is the main factor controlling the origin and evolution of these systems.

\section{INTRODUCTION}

Estuaries, back-barrier lagoons and pocket beaches constitute common sedimentary environments and biological habitats in rocky and wave-dominated clastic coasts. Less common elements are perched lakes (Riggs et al., 1995; Cooper et al., 2012), which are located at elevations that are higher than the relative sea-level in back-barrier basins fed by small rivers. In contrast to back-barrier lagoons, this elevation normally precludes the direct inflow of seawater into the system (Cooper et al., 2012).

This article is protected by copyright. All rights reserved. 
All of these littoral morpho-sedimentary systems are genetically related, and most of them formed during the Late Pleistocene-Holocene transgressive period. When sea-level rises, valleys and depressions close to the coastline are inundated, and rapid geomorphological and sedimentological changes occur. The architecture of the resulting transgressive sequence basically depends on the balance between the rate of sediment accumulation and the rate of increase in accommodation space driven by sea-level change, as well as by the nature of sediments supplied from the sea and the continent (Curray, 1964; Cattaneo \& Steel, 2003; Tesson, et al. 2011, Cooper et al., 2012, Hein et al. 2016). In addition to changes in sea-level and sedimentary budgets, climate variability can also play a significant role, especially in determining the stability of barriers, which are usually vulnerable to strong storm regimes (Andrade et al., 2004; Van Vliet-Lanoë et al., 2014a). This stability is also a function of changes in the vegetation cover (Jackson \& Cooper, 2011; González-Villanueva et al., 2013) or direct human intervention (Dinis et al., 2006).

Most models of the long-term sedimentary evolution of coastal systems with poor carbonate production are based on classic studies of present-day analogues and/or investigations of short-term morphodynamic changes in open coasts (e.g. Boyd et al. 1992, Niedoroda et al., 1985; Roy et al. 1995; Carrasco et al., 2016). Models of post-glacial coastal systems incorporating data about the antecedent pre-Holocene topography of the bedrock and detailed Holocene stratigraphies are less common (Tessier, et al., 2012; Hein et al., 2014; Fruergaard et al. 2015a,b). Among these, only a few have dealt with rocky coastal systems that included freshwater perched lakes separated from the open sea by extensive sand barriers (Devoy et al. 1996; Bao et al., 2007, Massey \& Taylor, 2007; Cooper et al., 2012) but they did not investigate the parameters and mechanisms involved in their formation from a sequential stratigraphy perspective.

Understanding the long-term evolution of coastal systems is key to implementing sound policies to address the impacts of climate on coastal regions (Day et al., 2008). Their sedimentary record can potentially be used, for instance, to reconstruct trends in storm frequency and/or intensity at different time scales (Chaumillon et al., 2017). However, sites from sedimentary environments, such as estuaries and back-barrier lagoons, are not often used for reconstructing palaeoclimate history because of the uncertainties regarding their geomorphic evolution (Gregory et al., 2015). In particular, continuous sediment preservation in back-barrier lagoons is hindered by strong hydrodynamic

This article is protected by copyright. All rights reserved. 
conditions and the lack of sufficient accommodation space (Fruergaard et al., 2011). In contrast, back-barrier perched lakes have relatively more stable depositional environments and sedimentation rates (Kempf et al., 2017), and these features make them good candidates for palaeoclimate (particularly palaeotempestology) studies (Liu, 2007). The study of such systems may help to reconstruct the storm dynamics (i.e. intensity and frequency) that have shaped the evolution of littoral depositional systems and habitats, such as the rocky north-west coast of Spain, which is characterized by a high-energy wave regime controlled by long-term variations in the North Atlantic storm tracks (Lozano et al., 2004; Orme et al., 2017).

The specific aims of this study are: (i) to describe the architecture and long-term Holocene evolution of the back-barrier coastal system of Doniños, which is located in the rocky coast of Galicia (northwest Spain), using sequential stratigraphic analysis and a robust age model; (ii) to identify the main forcing drivers that led to the formation of the present-day back-barrier perched lake in the Doniños coastal system; (iii) to review the Holocene history of coastal systems in this region (i.e. estuaries, back-barrier lagoons, pocket beaches and back-barrier perched lakes) and investigate the timing and dynamics of reconstructed major palaeoenvironmental changes and the regional sea-level evolution; and (iv) to propose a depositional model for back-barrier perched lakes in rocky coasts based on the Doniños site and others from the north-west Iberian Peninsula coast.

\section{DONIÑOS COASTAL SYSTEM SETTING}

\section{Geology, hydrology and bedrock topography}

The north-west coast of Spain (Galicia) is an abruptly shaped coastline that is characterized by promontories, cliffs that are up to $610 \mathrm{~m}$ high, embayed beaches, estuaries in drowned river valleys (rías), back-barrier lagoons, and back-barrier perched lakes (Fig. 1). The coast is developed over the plutonic and metamorphic rocks of the Variscan Chain (Iberian Massif), which is fractured along main north-west/south-east and north-east/south-west faults (Díez Montes et al., 2017). Although

Quaternary tectonic activity has been confirmed in the region (e.g. Martínez-Carreño \& García-Gil, 2017), no significant movements have been recognized since the Late Pleistocene (Blanco-Chao et al., 2003).

This article is protected by copyright. All rights reserved. 
The Doniños coastal system ( $43^{\circ} 29.5^{\prime} \mathrm{N}, 8^{\circ} 18.7^{\prime} \mathrm{W}$ ) occupies the lower part of the $3.5 \mathrm{~km}$ long valley of the O Regueiro River. The relatively large catchment (550 ha) mainly comprises Variscan biotiterich and muscovite-rich granitoids from the Ferrol Massif (Fig. 1; Díez Montes et al., 2017). This Variscan substrate forms a gently dipping surface to the beach line (the 'ramp'); vertical electrical sounding (VES) profiles performed parallel to the coast in the sand barrier have identified a fault at the shoreline and show an increase in bedrock surface dip towards the sea associated with this fault (López-Cancelo, 2004).

The continental shelf of north-west Iberia forms a gently dipping, north-bearing, 30 to $50 \mathrm{~km}$ wide geomorphological structure with a shelf break located at water depths of 160 to $180 \mathrm{~m}$. Sediments are dominated by continental inputs via riverine discharges, and they accumulate in the continental margin at rates of up to $1.5 \mathrm{~mm} \mathrm{yr}^{-1}$ (Rey et al., 2014). The shelf has been subjected to high sediment supply during the Holocene, as corroborated by the presence of prograding sandy sedimentary bodies (Martínez-Carreño et al., 2017).

A west-east transect in the Doniños coastal system enables the identification of (Figs 1 and 2): a beach foreshore-backshore fringe oriented to the NNE-SSW (33 to $63 \mathrm{~m}$ wide), a shore-parallel aeolian sand dune barrier (that is $1200 \mathrm{~m}$ long, 315 to $400 \mathrm{~m}$ wide, and located at an elevation of 6 to $13 \mathrm{~m}$ above mean sea-level, amsl), and a back-barrier freshwater lake with an almost rectangular shape (720 m maximum length, $400 \mathrm{~m}$ wide). The lake occupies 24.9 ha, with 4.4 ha corresponding to a shallow area with emergent macrophyte communities. The Doniños Lake is hydrologically perched, with a water level of approximately $5 \mathrm{~m}$ amsl. The bottom of the lake has an irregular topography and is located 3.5 to $5.0 \mathrm{~m}$ below mean sea-level. The lake is fed by the $2.8 \mathrm{~km}$ long O Regueiro River. During periods of intense rainfall, a channel located in the northern part of the sand barrier becomes functional and episodically drains the lake (Vilas \& Rolán, 1985). However, surface water exchange with the open sea is almost completely absent at present.

This article is protected by copyright. All rights reserved. 


\section{Sea and wind currents}

The north-west coast of Spain is a mesotidal wave-dominated coast, with an average tidal range of 2.75 m (maximum 4.40 m; data from Gijón and A Coruña seaports, year 2002). Wind records extending from 1940 to 2001 at A Coruña weather station, which is located $15 \mathrm{~km}$ to the south-west of Doniños, indicate that there are three main wind directions (González-Villanueva et al., 2013): (i) south-westerly winds associated with the passage of winter storms, which bring high-energy waves responsible for the offshore-onshore movement of sand on the beach; (ii) medium-intensity northwesterly summer winds that transfer sediment from the beach to the adjacent dune system; and (iii) low-intensity north-easterly summer winds responsible for sand movement within the dune field. The Doniños system is partially protected from the north-easterly winds by Monte Lobadiz (30 to $245 \mathrm{~m}$ amsl). In contrast, stronger winds and associated waves from the south-west and north-west directly impact the beach and aeolian sand barrier.

\section{Holocene sea-level}

During the Last Glacial Maximum (LGM), global sea levels were 120 to $130 \mathrm{~m}$ lower than they are now. During the post-LGM period, sea-level rose, and maximum rates were reached globally between 16.0 and $9.0 \mathrm{ka}$ cal BP (Lambeck et al., 2002). However, local and regional factors must be taken into account in order to estimate the variability in sea-level change at lower spatial scales (Leorri et al., 2012). Holocene sea-level changes since $11.2 \mathrm{ka}$ cal BP have been reconstructed for north-west lberia using data retrieved from cores in 40 coastal systems, mainly estuaries (Alonso \& Pagés, 2010). The composite curve shows four main phases in sea-level change (Fig. 3): (i) an Early Holocene phase (11.2 to $9.4 \mathrm{ka}$ cal BP) of rapid sea-level change at a rate of $11.5 \mathrm{~mm} \mathrm{yr}^{-1}$, which produced sea-level rise from approximately -27 to $-20 \mathrm{~m}$ amsl; (ii) a decelerating phase from 9.4 to $6.8 \mathrm{ka}$ cal BP with lower sea-level change rates ranging from 3.6-7.0 $\mathrm{mm} \mathrm{yr}^{-1}$; (iii) a mid-Holocene (6.8 to $4.2 \mathrm{ka} \mathrm{cal} \mathrm{BP}$ ) stabilization phase with very low rates $\left(0.2 \mathrm{~mm} \mathrm{yr}^{-1}\right)$ when sea-level stabilized at approximately -5 to $7 \mathrm{~m}$ amsl; and (d) a Late Holocene phase (4.2 ka cal BP to the present) with relatively higher rates of sea-level change $\left(1.2 \mathrm{~mm} \mathrm{yr}^{-1}\right)$. This pulsating Holocene sea-level rise caused the flooding of lowland coastal plains and estuarine areas. The coastal depositional sequences include progradational, shallowing upward estuarine sediment sequences with sand dune barrier complexes. The Holocene flooding of the coastal basins eroded the previously deposited Late Pleistocene sedimentary units in

This article is protected by copyright. All rights reserved. 
open coasts and cliffs (Alonso \& Pagés, 2007, 2010; Lorenzo et al., 2007; Arribas et al., 2010). Most coastal systems in this region show evidence of erosion associated with land use changes and human activities (Marcos \& Amores, 2014).

\section{MATERIALS AND METHODS}

In September 2012, four sediment cores up to $4.45 \mathrm{~m}$ long (cores D12-1A/1B, D12-2A/2B, D12-3A and D12-4A) were recovered from the Doniños back-barrier perched lake using a UWITEC ${ }^{\circledR}$ piston corer installed in a UWITEC ${ }^{\circledR}$ platform raft (UWITEC, Mondsee, Austria) following an inshore W-to-E transect (Fig. 1D). Cores were duplicated in two sites (D12-1A/1B and D12-2A/2B). All cores were split longitudinally and imaged using a high-resolution colour line scan camera.

Previously published data obtained from other deposits in the area were reviewed and included in the discussion. These include lithological and chronological data from a $4.20 \mathrm{~m}$ long core (DON-2) retrieved in the western margin of the lake (Santos et al., 2001), as well as data obtained from two cores located in the sand barrier reaching the basement at $26.60 \mathrm{~m}$ (Don-3 and Don-4: LópezCancelo, 2004) and data from a $4.4 \mathrm{~m}$ long offshore core (C-29, Fig. 1C) retrieved from the adjacent shoreface front at a water depth of $34 \mathrm{~m}$ (Mosquera-Santé, 2001). Structural data from two VES profiles crossing the sand barrier were also available (López-Cancelo, 2004).

Sedimentary facies analysis was performed based on the lithological characterization of the cores and on the microscopic analysis of smear slides of sediment samples taken every $5 \mathrm{~cm}$ in core D12-3A ( $\mathrm{n}$ $=68)$, as well as on additional samples obtained from other cores $(n=12)$. Sediment texture and composition were determined in short cores to define the depositional environments within the lake. A stratigraphic correlation panel, including the architectural relationships between sedimentary bodies, was constructed using lithological unit boundaries and erosive discontinuities. These have been visually recognized in cores and photographs or inferred from time-gaps detected by absolute chronology. The location and morphology of the bedrock surface were reconstructed using the data provided by all the cores that reached the basement (Don-3, Don-4, D12-2A and D12-4A; Fig 1D).

This article is protected by copyright. All rights reserved. 
X-ray fluorescence (XRF) analyses were carried out on the selected master core D12-3A using the AVAATECH XRF II core scanner (Avaatech BV, PS Alkmaar, The Netherlands) from the Universitat de Barcelona. The XRF measurements were made every $2 \mathrm{~mm}$. Thirty-two chemical elements were measured, but only nine elements ( $\mathrm{Al}, \mathrm{Si}, \mathrm{K}, \mathrm{Ca}, \mathrm{Ti}, \mathrm{Mn}, \mathrm{Fe}, \mathrm{Sr}$ and $\mathrm{Zr}$ ) yielded signals with sufficient intensity (counts per second) to be considered statistically significant.

Core D12-3A was sampled every $4 \mathrm{~cm}$ for mineralogical analysis $(n=114)$. To characterize all facies, some samples $(n=40)$ were taken in the remaining cores. Surface sediment samples from the beachbarrier complex $(n=8)$, representing the potential modern analogues of the fossil facies, were also analysed. All samples were dried at $60^{\circ} \mathrm{C}$ for $48 \mathrm{~h}$ and manually ground using an agate mortar. Mineralogical analyses were carried out using X-ray diffraction (XRD) using a SIEMENS-D500 automatic X-ray diffractometer (Cu-Ka, 40 kV, 30 mA; Siemens, Munich, Germany) with graphite monochromator at the CCiT of the Universitat de Barcelona. The identification and quantification of the relative abundances of the different mineralogical species present in the crystalline fraction were carried out following the standard procedure based on the matrix-flushing theory (Chung, 1974a,b).

Samples were analysed for their total organic carbon (TOC) contents. Sediments were first treated with diluted $(1: 4) \mathrm{HCl}$ to eliminate minor amounts of carbonates. The analyses were carried out using a ThermoFinnigan FlashEA1112 elemental analyser (Thermo Fisher Scientific, Waltham, MA, USA) at the Servizos de Apoio á Investigación of the Universidade da Coruña. Total sulphur (TS; pyrite + organic sulphur) contents were also analysed using a Carlo Erba 1108 elemental analyser (CE Elantech, Lakewood, NJ, USA) at the Centres Científics i Tecnològics de la Universitat de Barcelona (CCIT-UB).

Samples assessed for their microfossil content (mainly diatoms and sponge spicules) were taken every $4 \mathrm{~cm}(n=114)$ in core D12-3A and in selected intervals of the remaining cores. Microscopy slides used for the analysis of diatoms and sponge spicules were prepared following the procedures of Renberg (1990) and Harrison (1988), respectively, and checked with a Nomarsky differential interference contrast microscope at magnifications of X1000 and X100. The abundances of both diatom and sponge spicules were estimated using a semi-quantitative approach (Sancetta, 1979) to

This article is protected by copyright. All rights reserved. 
aid in the description of the main facies. Scanning electron microscopy (SEM) was also used to support the identification of some problematic diatom and sponge taxa.

The chronostratigraphy of the sedimentary model was constructed using 39 AMS ${ }^{14} \mathrm{C}$ dates of pollen concentrate and organic-rich soil samples obtained from selected levels in the cores (Table 1). The AMS ${ }^{14} \mathrm{C}$ dates were calibrated to calendar years (cal BP) using the CALIB 7.1 software (Stuiver \& Reimer, 1993) and the INTCAL13 curve (Reimer et al., 2013), selecting the median of the $95.4 \%$ distribution ( $2 \sigma$ probability interval). Five published radiocarbon dates from offshore, sand-barrier, and freshwater marsh cores (López-Cancelo, 2004, Mosquera-Santé, 2001, and Santos et al., 2001) were also used to construct the chronostratigraphic model. All radiocarbon ages are reported in calibrated years relative to $1950 \mathrm{AD}$.

Sedimentation rates $\left(\mathrm{cm} \mathrm{yr}^{-1}\right)$ were estimated based on the radiocarbon dates and differences in thickness between the upper and lower limits of each lithological unit in core D12-3A. Mechanical compaction due to coring, as estimated by subtracting the thickness of sediments recovered from the absolute depth drilled in each core, yielded values ranging from 9 to $15 \%$. To estimate the effects of compaction produced by the load of the overlying deposits in the muddy intervals (Units 5 and 6), sediment fluxes were calculated $\left(\mathrm{g} \mathrm{cm}^{-2} \mathrm{yr}^{-1}\right)$ by multiplying the estimated sedimentation rates by the average dry bulk densities $\left(\mathrm{g} \mathrm{cm}^{-3}\right)$ of these intervals. The obtained sediment fluxes varied between $0.03 \mathrm{~g}$ and $0.05 \mathrm{~g} \mathrm{~cm}^{-2} \mathrm{yr}^{-1}$ for Units 5 and 6 , respectively. Although differences in sediment flux can be as high as $60 \%$, compaction due to sediment load was considered not significant; thus, no correction was applied to the estimated sedimentation rates.

\section{RESULTS AND INTERPRETATION OF FACIES AND LITHOLOGICAL UNITS}

A total of eight Holocene lithostratigraphic units overlying the Palaeozoic bedrock have been defined and interpreted in the Doniños coastal system based on the analysis of cores and, to a lesser extent, recent surface sediments (Fig. 4).

This article is protected by copyright. All rights reserved. 


\section{Palaeozoic bedrock}

Palaeozoic bedrock was reached in cores Don-3, Don-4, D12-2A and D12-4A. The bedrock surface has an undulating morphology with an onshore slope increase (1:100 to 1:50; Fig. 4). It comprises Palaeozoic granites with a grey, mica-rich alteration interval at the top that is composed of finegrained material grading to sandy material (Table 2). The non-altered granite is composed of quartz (34\%), plagioclase (24\%), muscovite (21\%) and K-feldspar (19\%). The altered granite (cores D12-2B and D12-4B), is composed of quartz (60\%), muscovite (29\%), K-feldspar (11\%) and plagioclase (3\%), with subordinate amounts of kaolinite with a sandy mudstone texture (Facies Bra, Table 2). This altered granite interval identified in the inner part of the ramp is interpreted to represent a regolith caused by the intensive in situ weathering of the substrate.

\section{Unit S - Pre-inundation ramp palaeosol (>10.2 ka)}

A palaeosol horizon has been identified in the middle part of the present-day lake over the lowgradient granite bedrock surface (Unit S, core D12-2B). This horizon is composed of fine-grained regolith material overlying the altered granite basement (Facies Bra), and it includes some in situ root remains dated to $10.2 \mathrm{ka}$ cal $\mathrm{BP}$ (Table 1; Fig. 5A). The occurrence of this horizon points to a vegetated alluvial plain that developed before the Holocene transgression.

During this pre-inundation stage, aeolian deposits accumulated in the western shoreface of the Doniños beach at -34 m amsl (core C-29, Mosquera-Santé, 2001). These deposits are overlain by back-barrier lagoon sediments dated to $13.6 \mathrm{ka}$ cal BP, which were covered with marine sediments until the present (Mosquera-Santé, 2001).

\section{Unit 1 - Early Holocene sand-barrier deposits (10.2 to $8.0 \mathrm{ka})$}

Unit 1, which is found in cores D12-1B and D12-2B, is composed of a $60 \mathrm{~cm}$ thick interval of white, medium to coarse-grained, homometric, low-matrix sand. The basal surface is erosive over the granite substrate and the palaeosol. The sand grains mainly comprise quartz (89\%), K-feldspar (2\%) and plagioclase (9\%); neither mica nor carbonate grains are present. In core D12-1B, which is located closer to the sea, sand is dark grey and includes marine mollusc shell bioclasts. The textures,

This article is protected by copyright. All rights reserved. 
mineralogical maturity, and stratigraphic distribution of these facies indicate that they mainly correspond to aeolian facies (Facies Eo) that accumulated over the palaeosol close to the shoreline during an early transgressive phase in the area (Figs 4 and $5 \mathrm{~A}$ ).

The age of Unit 1 is constrained by the radiocarbon age of the palaeosol (Unit S, $10.2 \mathrm{ka} \mathrm{cal} \mathrm{BP}$ ) and the base of the non-depositional gap over Unit 3 (8.0 ka cal BP). Unit 1 resembles aeolian deposits that accumulated in the shoreface of the Doniños beach (core C-29, Mosquera-Santé, 2001) and could therefore correspond to a sand barrier formerly located at a depth of $34 \mathrm{~m}$ and a distance of 2 $\mathrm{km}$ offshore the present-day Doniños beach that migrated towards the coast during transgression.

\section{Unit 2 - Open bay marine deposits (9.1 to $8.0 \mathrm{ka})$}

Unit 2 was recovered in the lower sections of cores D12-3A, Don-3, Don-4 and D12-1B. It shows a seaward increase in thickness up to a maximum depth of $8.8 \mathrm{~m}$. The ages of this unit range from 9.1 to $8.0 \mathrm{ka}$ cal BP (Fig. 4). It extends offshore, where it overlies the aeolian and back-barrier lagoon deposits recorded at the base of the offshore core C-29 (Mosquera-Santé, 2001).

Unit 2 is mostly composed of green, bioclastic, coarse to fine-grained sand (Facies Ma) (Fig. 5B; Table 2). A gravel interval overlies an erosive surface in the lower part of the unit. In the sand barrier cores (Don-3 and Don-4), the unit also includes some intervals with aeolian textures (i.e. good roundness, homometric sand grains) and mottled patterns produced by organic matter aggregates

during the transition to Unit 5. The sedimentation rate for Unit 2 in core D12-3A was $0.7 \mathrm{~mm} \mathrm{yr}^{-1}$ (Fig. $6)$.

In core D12-3A, calcite and aragonite bioclasts represent 3.5\% of the mineralogical composition of the sand (Fig. 7; Table 2). Bioclasts are dispersed in both sediment and layers; they comprise shell fragments and complete shells that are mainly those of marine bivalves (Pecten sp.) and gastropods and secondarily those of eroded echinoderm spikes and foraminifera tests. Silicate sand grains have subrounded to angular shapes and are dominated by quartz (56\%), with subordinate quantities of plagioclase (11\%), K-feldspar (16\%), mica (7\%) and other silicates (Table 2). Pyrite is absent, and its TOC and TS values are almost null. The Ca content is by far the highest for the entire core D12-3A due to the presence of bioclasts. The Ti content is also high and exhibits a decreasing trend, mirroring normal grading textures.

This article is protected by copyright. All rights reserved. 
The semi-quantitative analysis of diatoms in Unit 2 in core D12-3A shows an assemblage (Diatom Assemblage Zone D12-3A-1, Fig. 7) that is dominated by the marine tychoplanktonic Paralia sulcata, with minor contributions of the marine/brackish epipsammic diatoms Dimeregramma minus and Planothidium delicatulum. This assemblage is typical of neritic subtidal conditions (Vos \& De Wolf, 1993; McQuoid \& Hobson, 1998). Occasional fragments of the freshwater Aulacoseira spp. also appear at the bottom of this unit, probably indicating the reworking of pre-inundation lacustrine deposits and/or allochthonous inputs from the continent. Sponge spicules are dominated in this unit by the marine taxa Prosuberites denhartogi, Haliclona cinerea, Phorbas sp. and Myxilla sp. Microscleres of the freshwater Spongilla lacustris, as well as gemmuloscleres of this species and those of the freshwater Racekiela ryderii, are also present, but in low abundances. Most of the spicules show a high degree of fragmentation, indicating a high-energy system and the transport of remains. Some entire megascleres also show corrosion, probably due to the higher solubility of silicon in alkaline environments provided by marine $\mathrm{pH}$ values (Kamatani \& Oku, 2000). These sponge data are compatible with the existence of an open bay system with reduced freshwater inputs.

The textural features, geochemical composition and biological content of Unit 2 are similar to those of recent sediments (Table 2) from shoreface-foreshore deposits and (mottled) backshore deposits with vegetation cover and aeolian influence. These deposits occupied the shore fringe of the Doniños beach and were accumulated during the rapid and erosive Late Pleistocene (outer ramp) and Early Holocene (inner ramp) transgression. This transgressive phase produced the significant erosion of both the granite bedrock surface and the soils that developed over it.

\section{Unit 3 - Lagoonal deposits (8.6 to $8.0 \mathrm{ka}$ )}

Unit 3 sediments have only been recovered in the eastern middle part of the present-day lake (core D12-3A). The $67 \mathrm{~cm}$ thick interval comprises sandy dark brown to black banded mud (Facies Lg) with up to eight grey interbeds of thin, discontinuous, coarse sand layers (Facies Sd). The deposition of Unit 3 occurred from 8.6 to $8.0 \mathrm{ka}$ cal BP, and its sedimentation rate is similar to that of the marine deposits of Unit 2 (0.6 mm yr ${ }^{-1}$, Fig. 6). Unit 3 overlies the marine deposits of Unit 2 with temporal continuity, and it is covered by the lacustrine deposits of Unit 5 through a paraconformity surface, with a significant time gap (Gap 1, Fig. 4).

This article is protected by copyright. All rights reserved. 
The mineral composition of this unit is similar to that of the marine sediments from Unit 2, but carbonate minerals are absent, its plagioclase content is higher $(18 \%)$, and pyrite is present $(3 \%)$. Its moderate values of $\mathrm{Ti}$ and $\mathrm{Fe}$ are explained by the presence of coarse materials and pyrite (Fig. 7). The TOC (up to $20 \%$ ) and TS (up to $4.5 \%$ ) contents show a sharp increase compared to those of the former marine deposits, reaching their maximum values for the entire core D12-3A (Fig. 7). These values point to high-productivity conditions in a back-barrier lagoon environment.

The diatom assemblages in this unit show a sharp decline in Paralia sulcata until it disappears. The bottom of the unit (Diatom Assemblage Zone D12-3A-2, Fig. 7) is co-dominated by Paralia sulcata, the also marine tychoplanktonic Rhaphoneis spp., the marine/brackish epipsammic Opephora mutabilis and a mixture of brackish/freshwater taxa, including the tychoplanktonic Pseudostaurosira subsalina and Diatoma tenuis, as well as epyphitic Cocconeis spp. The rest of the unit (Diatom Assemblage Zone D12-3A-3) is dominated by brackish/freshwater and marine/brackish tychoplanktonic and epiphytic species of the Fragilaria complex, mainly P. subsalina and Pseudostaurosira elliptica. The shift in the dominance of marine to marine/brackish and brackish/freshwater diatoms indicates a change to a brackish back-barrier environment. The Paralia sulcata - Fragilaria spp. transition is a characteristic indicator of the contact between marine and continental sediments when a former marine basin is being isolated from the sea (e.g. Zong, 1997). As in Unit 2, sponge remains are dominated by the marine P. denhartogi, H. cinerea, Phorbas sp. and Myxilla sp. Microscleres and gemmuloscleres of the freshwater S. lacustris and R. ryderii constitute a minor component of the assemblages. Spicule fragmentation is strongly reduced compared to Unit 2, indicating a low-energy environment.

Sedimentological, geochemical and micropalaeontological data indicate that Unit 3 corresponds to a shallow back-barrier lagoon environment that was separated from the sea by the coastal sand barrier represented by Unit 1.

This article is protected by copyright. All rights reserved. 


\section{Unit 4 - Channelized alluvial deposits (8.3 ka)}

Unit 4 is only present in core D12-4A, where it occurs above the bedrock and below the erosive surface at the base of Unit 5 . It is composed of up to $25 \mathrm{~cm}$ thick layers of black sandy mud, with 10 $\mathrm{cm}$ thick channelized sand deposits. Its sand grains are angular and heterometric and are composed of quartz $(39 \%)$, mica $(28 \%)$, plagioclase $(20 \%)$ and feldspar $(13 \%)$; these proportions are similar to those found in recent fluvial sediments (Table 2).

Channelized sand is characterized by a low diatom content, with very common fragmented valves, dominated by freshwater species belonging to the periphytic Fragilaria s.l., Eunotia spp., Gomphonema spp. and Pinnularia spp. Some samples from black mud are moderately rich in diatoms, whereas others are almost barren. Gemmuloscleres, megascleres and microscleres of the freshwater sponge S. lacustris are also present. Spicules of this species are less abundant and more fragmented in the channelized sand than in the black mud of this unit. No corrosion was observed in the spicules.

Radiocarbon dating indicates that the deposits of this unit are coetaneous with the lagoonal deposits of Unit 3 but are located in the mainland emergent margin of the basin. The erosive gap spans $3.8 \mathrm{ka}$. Unit 4 is interpreted as channelized fluvial deposits incised in a muddy alluvial plain that was flooded and supplied by both water and sediments from the mainland.

\section{Unit 5 - Early lake deposits (4.5 to $1.1 \mathrm{ka})$}

Unit 5 occurs in all barrier and lake cores, with a maximum thickness of $153 \mathrm{~cm}$ in core D12-3A (Fig. 4). It is mainly composed of sandy brown mud (Lk) with interbedded sand layers in the eastern margin of the lake (facies Sd in core D12-4A). Its deposition ranged from 4.5 to $1.1 \mathrm{ka}$ cal BP. This unit overlies a sedimentary discontinuity (Gap-1) that encompasses most of the mid-Holocene (8.0 to 4.5 ka cal BP). Compared with those observed in the lagoon (Unit 3) and marine (Unit 2) deposits, the sedimentation rate determined in core D12-3A for Unit 5 is higher, reaching up to $1.1 \mathrm{~mm} \mathrm{yr}^{-1}$ (Fig. 6).

This article is protected by copyright. All rights reserved. 
The mineralogical composition of this unit demonstrates that its main constituents are quartz (42\%), plagioclase (23\%), K-feldspar (13\%) and mica (7\%). These proportions are similar to those of the unaltered granitoid, as expected from younger deposits containing less altered feldspar and plagioclase (Table 2). Pyrite (4\%) is also present. Total organic carbon values of up to $12.8 \%$ are indicative of moderate productivity conditions. Total sulphur exhibits a decreasing trend from 3 to $1 \%$.

The bottom of this unit in core D12-3A (Diatom Assemblage Zone D12-3A-4, Fig. 7) is characterized by the codominance of periphytic brackish/freshwater and freshwater diatoms, such as Achnanthidium minutissimum, Cocconeis placentula, Stauroforma exiguiformis and $D$. tenuis. Occasional resting spores of the marine euplanktonic Chaetoceros spp. also appear at the bottom of the unit. This earlier diverse assemblage is replaced by the dominance of the freshwater euplanktonic Aulacoseira ambigua, with A. minutissimum as subdominant taxa (Diatom Assemblage Zone D12-3A5). Other components of this assemblage also include the freshwater euplanktonic Aulacoseira granulata and the freshwater tychoplanktonic S. exiguiformis. Chaetoceros spp. resting spores disappear in this part of the unit, except in its uppermost levels. The younger sediments of Unit 5 are also preserved in the sand barrier cores Don-3 and Don-4 (Fig. 4). Core Don-3 has an identical diatom assemblage as Diatom Assemblage Zone D12-3A-5, suggesting that similar ecological conditions existed at this more distal location until $1.3 \mathrm{ka}$ cal BP. In the outer core Don-4, this unit is dominated by the freshwater epiphytic $A$. minutissimum and by the brackish/freshwater tychoplanktonic Fragilariforma exigua. These diatom assemblages point to shallower and more marine-influenced environments in this outer location than are recorded at the core Don-3 site.

The reported diatom assemblages are typical of non-tidal lakes (Vos \& De Wolf, 1993). The transition from a periphytic to euplanktonic-dominated assemblage is characteristic of the transition from shallow to moderately high-water environments (Wolin \& Stone, 2010). These data suggest the existence of a lacustrine environment with no or very reduced sea influence. This would be restricted to the seaward positions of the system and to times of enhanced storminess, as suggested by the occasional presence of Chaetoceros spp. resting spores, which represent an allochthonous component that could effectively be transported to the lake by sea spray (Lee \& Egglestone, 1989). These episodes are concentrated at the bottom and top of the unit.

This article is protected by copyright. All rights reserved. 
This unit is characterized by the dominance of freshwater sponges, which mainly comprise $R$. ryderii, with S. lacustris as an accompanying species. Spicules of marine taxa are restricted to the basal level, where they occur in very low abundances and disappear thereafter. Almost all spicules show no signs of fragmentation or corrosion, suggesting a low-energy environment and circumneutral or mildly acidic $\mathrm{pH}$ conditions (Harrison, 1988).

Radiocarbon data indicate that Gap-1, which is located between Units 2/3 and 5, contains two temporal components: (i) an older non-depositional component that corresponds to the lack of likely lagoonal sedimentation under stable sea-level conditions; and (ii) a younger non-depositional component generated by the westward alluvial prograding pattern (downlap 1) of Unit 5 over Unit 2, once the new sand barrier was constructed under transgressive conditions. Both components together produce an east to west time increase in the gap, with ages ranging from 8.3 to $4.5 \mathrm{ka}$ cal BP (core D12-4A), 8.0 to $3.7 \mathrm{ka}$ cal BP (core D12-3A) and 8.1 to $1.75 \mathrm{ka}$ cal BP (core D12-1B).

\section{Unit 6 - Late lake deposits (1.1 ka to Recent)}

The deposits of Unit 6 cover the bottom of the present-day lake (cores D12-1A/1B, D12-2A/2B, D12$3 \mathrm{~A}$ and D12-4B, Fig. 4). This unit is composed of brown mud with some dispersed and clustered sand grains (Lks). These sand grains are scarcer at the top of the unit (Facies Lk). Unit 1 increases in thickness from the western to the eastern lake margin, where the maximum accumulation of terrigenous sediments occurs. The unit was radiocarbon dated to $1.1 \mathrm{ka}$ cal BP to the present. In core D12-3A, this unit has the highest sedimentation rate (2.3 $\left.\mathrm{mm} \mathrm{yr}^{-1}\right)$ (Fig. 6). Quartz (35\%), plagioclase (25\%), feldspar (21\%) and mica (7\%) show proportions that are very similar to those of the nonaltered granite and the lake deposits of Unit 5. The TOC contents range from 8 to $11 \%$. Total sulphur notably increases compared to Unit 5 , as does pyrite, which reaches values of up to $12 \%$.

Despite the similar lacustrine origins of Unit 5 and Unit 6, they show significant differences in their diatom compositions (Fig. 7). The lower part of Unit 6 (Diatom Assemblage Zone D12-3A-6) shows the dominance of freshwater periphytic diatoms, which are mainly $D$. tenuis and secondarily $A$. minutissimum, thus suggesting a freshwater shallow environment. Both species thereafter become subdominant diatoms when the assemblages become dominated by Synedropsis $\mathrm{sp}$. aff.

This article is protected by copyright. All rights reserved. 
roundii/karsteteri (Diatom Assemblage Zone D12-3A-7). Although the ecology of the genus Synedropsis is still not well known, both S. roundii and S. karsteteri are regarded as bloom-forming brackish to freshwater planktonic (probably meroplanktonic) diatoms (Melo et al., 2003). These data suggest shallower and more saline conditions compared to the lacustrine facies of the former Unit 5. The top of Unit 6 shows a noticeable change in its diatom assemblages (Diatom Assemblage Zone D12-3A-8), which become dominated by the freshwater euplanktonic A. ambigua, A. granulata and Fragilaria crotonensis. The presence of Synedropsis sp. aff. roundii/karsteteri is strongly reduced, and it becomes a subdominant taxon. This latter assemblage somewhat resembles the diatom composition of Diatom Assemblage Zone D12-3A-5 (Unit 5) and indicates a change to a more restricted and deeper freshwater environment. This diatom composition is similar to that currently found in the water column. Spicules of $S$. lacustris and, mainly, $R$. ryderii, dominate the sponge content of this unit. Spicules of marine sponges are absent.

\section{Unit 7 - Alluvial lake margin deposits (1.1 ka to Recent)}

Unit 7 only occurs in core DON-2 at the eastern margin of the lake (Santos et al., 2001). The bottom of this core, which does not reach the bedrock, was dated to $0.54 \mathrm{ka}$ cal BP. These $4.2 \mathrm{~m}$ thick deposits consist of very coarse to fine-grained mica-rich sands with internal erosive surfaces (facies Al) and some interbedded organic-rich muddy layers (facies Lk). Both the inland marginal location and the mica-rich coarse-grained sediment contents indicate that this deposit corresponds to alluvial sediments transported to the lake by the O Regueiro River.

The diatom assemblages in core DON-2 (Santos et al., 2001) show a silting up of this margin, as suggested by the reduction of euplanktonic diatoms at the bottom ( $A$. ambigua and Discostella stelligera), which are replaced further up-unit by epiphytic diatoms (mainly $A$. minutissimum), and the appearance of aerophilous taxa, such as Hantzschia amphioxys and Luticula mutica, at the top of the sequence. The uppermost levels that contain diatoms (at depths of 100 to $150 \mathrm{~cm}$ ) show a marine/brackish epiphyte, Ctenophora pulchella, as a codominant taxon, suggesting more saline conditions or an increase in conductivity caused by enrichment in dissolved organic carbon.

This article is protected by copyright. All rights reserved. 


\section{Unit 8 - Aeolian barrier and backshore (4.5 ka to Present)}

The deposits of Unit 8 dominantly comprise white-yellowish, medium to coarse-grained sand that overlie the lacustrine deposits of Unit 5 and are up to $15 \mathrm{~m}$ thick. The sand grains exhibit homometric and rounded grain textures (Facies Eo, in cores Don-3 and Don-4). They are composed of quartz (73\%), plagioclase (10\%), feldspar (13\%), and variable quantities of carbonate (abraded marine shell bioclasts) and micas (Table 2).

The petrological features of the deposits of Unit 8 and their comparison with recent aeolian sands in the present-day sand barrier (Facies Eo) indicate that they correspond to aeolian sand dunes and backshore deposits. Both the composition and texture of these sandy deposits suggest that they primarily originated from coastal sands reworked by aeolian processes that eventually accumulated to form barrier dunes.

\section{DISCUSSION}

\section{Sediment provenance of the Doniños coastal system}

The textural and mineralogical composition analyses of downcore and surface sediments in the Doniños coastal system enabled a distinction to be made between two main sediment types based on their origin: (i) sandy sediments transported from the sea to the coastal system by marine or wind processes; and (ii) organic matter-rich, coarse to fine-grained sediments transported from the continent to the coastal system by fluvial processes.

The sandy sediments of the first group contain the barrier and coastal deposits of Units 1,2 and 8 , which consist of a mixture of mature siliciclastic grains with variable amounts of bioclastic carbonate grains. These sediments are formed entirely from shelf-derived materials and those from the coastal domain, which have been reworked, transported landward by wave-induced currents, and eventually reworked by aeolian processes. Many of these sands could have been inherited from Late Pleistocene coastal deposits (Alonso \& Pagés, 2007; Arribas et al., 2010). Despite the difficulties associated with accurately estimating changes in sand accumulation on the continental shelf adjacent to the Doniños coastal system, regional data indicate that a considerable transfer of sand from the shelf to the coast occurred throughout the Holocene period (González-Villanueva et al., 2015).

This article is protected by copyright. All rights reserved. 
The petrological features of the muddy and organic matter-rich sediments that accumulated in both the lagoon (Unit 3) and the lake (Units 5 and 6) suggest that they were first generated by the alteration of granite rocks in the catchment of the $O$ Regueiro River and were later transported by alluvial-fluvial currents to the back-barrier basin. The alluvial-fluvial deposits also include the proximal, coarse-grained and low-maturity sediments of Unit 7, which overall form a sedimentary wedge whose thickness diminishes from west to east (Fig. 4). The back-barrier retention and accumulation of these sediments have occurred since the partial or total closure of the sand barrier at $8.0 \mathrm{ka}$ cal BP. Before the formation of the barrier, fine-grained terrestrial sediments by-passed this zone to ultimately reach the sea.

\section{Sequence stratigraphy and palaeogeographical evolution of the Doniños coastal system}

The sequence stratigraphy and palaeogeographical evolution of the Doniños coastal system have been constructed using the architecture based on the sedimentary units, facies distribution, and Holocene sea-level changes established for north-west Spain by Alonso \& Pagés (2010) (Fig. 8). Two major stages in the evolution of this system have been distinguished: (i) the late stage of the transgressive systems tract (TST), which occurred during the rapid sea-level rise between $10.2 \mathrm{ka}$ and $4.5 \mathrm{ka}$ cal BP; followed by (ii) the highstand systems tract (HST), which occurred during the moderate sea-level-rise episode (with average values of $1 \mathrm{~mm} \mathrm{yr}^{-1}$ ) occurring from $4.5 \mathrm{ka}$ cal BP to today (Fig. 8A). Although the sedimentary record of the lowstand systems tract (LST) was not recovered, it corresponds to the continental sediments deposited in the present-day outer shelf during the Last Glacial Maximum (LGM). This is supported by the existence of freshwater diatom-rich deposits in the Galician outer shelf at depths of 150 to $160 \mathrm{~m}$ (Bao et al., 1997). These data indicate that the sea-level was below this depth range and was probably close to the shelf break at a depth of $180 \mathrm{~m}$ (Rey et al., 2014).

The oldest recorded deposition of the TST is represented by aeolian sediments located at the shelf at -34 m amsl that yielded a radiocarbon age of $15.9 \mathrm{ka}$ cal BP (lower interval of core C-29) (phase I, Figs 8 and 9). These data indicate that the shoreline was approximately $2 \mathrm{~km}$ offshore the present-day beach and that sea-level rise was very rapid (approximately $11.5 \mathrm{~mm} \mathrm{yr}^{-1}$ ). Moreover, TST sediments were deposited some tens of metres above the LST. The sea flooded the gentle sloping ramp formed

This article is protected by copyright. All rights reserved. 
at the bottom of the O Regueiro River valley at some point after $10.2 \mathrm{ka}$ cal $\mathrm{BP}$, as indicated by the age of the palaeosol covering the granite bedrock surface and producing a wave ravinement surface (WRS) (Fig. 4B). Most of the valley was rapidly flooded, resulting in the deposition of the barrier and marine sediments of Units 1 and 2, which onlap the WRS. This marine sedimentation corresponds to low sedimentation rates, coarse shallow sediments generated by high-energy waves and tidescouring currents that were more intense in the outer part of the ramp (cores Don-4 and Don-3).

At the beginning of the second TST phase (10.2 to $8.6 \mathrm{ka}$ cal BP), sea-level rose at a lower rate (approximately $7.0 \mathrm{~mm} \mathrm{yr}^{-1}$ ) until reaching a depth of $-14 \mathrm{~m}$ amsl (phase lla, Fig. 8). At the end of the second TST phase (phase Ilb, 8.6 to $8.0 \mathrm{ka} \mathrm{cal} \mathrm{BP}$ ), the rates of sea-level rise in the bay continued to decrease (reaching values of approximately $3.6 \mathrm{~mm} \mathrm{yr}^{-1}$ ) until sea-level reached $-10 \mathrm{~m}$ amsl. As a consequence, a barrier-lagoon system (Units 1 and 3) was progressively created in an inner-bay location (Fig. 9). Some of the equivalent mainland alluvial deposits have been preserved in the innermost positions of the valley (Unit 4), but most were eroded, generating the erosional component of Gap 1 (Fig. 8).

During the third and final phase of the TST (phase III, 8.0 to $4.5 \mathrm{ka} \mathrm{cal} \mathrm{BP),} \mathrm{the} \mathrm{sea-level} \mathrm{rise} \mathrm{was}$ approximately $0.2 \mathrm{~mm} \mathrm{yr}^{-1}$, reaching -7 to $-6 \mathrm{~m}$ amsl, when it almost stabilized at the maximum flooding surface (MFS) (phase III, Figs 8 and 9). The Doniños coastal system does not record the complete sedimentation history of this entire phase, which encompasses the mid-Holocene period, as indicated by the large sedimentary gap between Units $1 / 2 / 3$ and Unit 5 in the central area of the bay (i.e. the non-depositional component of Gap 1, which is older than the MFS, Fig. 8). This is interpreted as a non-depositional gap produced by the negligible sedimentation rates that occurred during sealevel stabilization between $6.8 \mathrm{ka}$ and $4.2 \mathrm{ka}$ cal BP, which largely reduced accommodation space. An intertidal lagoon scenario similar to that recorded in Unit 3 seems likely to have occurred during this phase (Fig. 9).

During the following phase (phase IV, Fig. 8), the moderate rates of sea-level rise favoured the construction of a narrow and probably few metres high sand barrier comprising marine sediments reworked from the nearshore (lower part of Unit 8 and lateral equivalent of Unit 2). The increased sediment availability at this time was therefore the by-product of a nearer sediment source associated

This article is protected by copyright. All rights reserved. 
with the landward migration of the barrier, as was already suggested by Roy et al. (1994). As a result, a freshwater lake was formed in the back-barrier basin (Unit 5). The consequences of this palaeogeographic reconfiguration were: (i) a marked change in the type of sedimentation, with sediments becoming more fine-grained, more organic-rich, and sourced from the continent; (ii) an abrupt shift in the depocentre of the basin from the western to the eastern part of the ramp; and (iii) the commencement of a phase of high accretion and sedimentation rates that lasted throughout the entire Late Holocene. The lacustrine sediments of Unit 5 show a progradational seaward pattern over the sediments of Units 2 and 3, thus generating the Gap 1 component that post-dates the MFS (Figs 8 and 9). The progradational downlap (downlap 1) created on the marine and lagoonal deposits extended from 4.5 to $1.8 \mathrm{ka}$ cal BP. This change from a retrogradational to a progradational sedimentary regime, as well as the almost complete isolation of the back-barrier basin from the sea, allows the authors to establish the MFS at the top of Units 2 and 3 as a likely isochronous surface with an age of $4.5 \mathrm{ka} \mathrm{cal} \mathrm{BP} \mathrm{(Figs} 4$ and 8). Although the marine and lagoon sediments of Units 2 and 3 have been slightly eroded, it is estimated here that when the topmost sediments of Unit 3 were deposited, the tidal regime extended up to the innermost positions of the basin. This study also establishes that the onset of the HST, which lasted throughout the entire Late Holocene, occurred at this time.

At $1.1 \mathrm{ka}$ cal BP, an episode of barrier breaching occurred, as indicated by the presence of allochthonous marine diatoms at the top of Unit 5. This breaching and the associated drainage of the lake caused the lake-level to drop several metres until it matched the coeval sea (base) level (phase V, Fig. 8). The drop in water level exposed lake sediments to erosion by alluvial-fluvial processes, thus incising a drainage network into the lake sediments (older component of Gap 2, which pre-dates LEES, Figs 8 and 9). The ages of the sediments below the top erosive surface of Unit 5 indicate that this erosion decreased from east to west (Figs 4 and 8). Following the partial emptying of the lake, the back-barrier system was exposed to the increased influence of seawater, which was favoured by a breached sand barrier.

This article is protected by copyright. All rights reserved. 
The second phase of the HST period (1.1 ka cal BP to today, phase VI, Fig. 8) was characterized by increased sedimentation during the final stages and eventual closure of the sand barrier (Fig. 9). Maximum sedimentation rates were reached, accompanied by the widening and progradation of the sand barrier to the sea (Unit 6 and upper Unit 8) and the subsequent moderate regression of the sea side of the barrier (regressive surface, RS, Fig. 4). The deposits of Unit 6 accumulated during this phase, covering the lacustrine deposits of Unit 5 and showing a gentle progradational pattern (downlap 2) that generated the younger component of gap 2, which post-dates LEES. The presentday configuration of the Doniños coastal system, i.e. a 315 to $400 \mathrm{~m}$ wide, 6 to $13 \mathrm{~m}$ high aeolian sand barrier, as well as a perched lake located at $5 \mathrm{~m}$ amsl, were progressively developed during this phase.

\section{Comparison of perched lakes with other rocky coastal sedimentary environments in the Galician coast}

The north-west coast of Spain consists of three main types of rocky, wave-dominated sedimentary systems: (i) pocket beaches, with or without dune systems, that are attached to the bedrock; (ii) permanently flooded open estuaries in rías and tide-influenced back-barrier lagoons, which are connected with fluvial catchments that are larger than $10 \mathrm{~km}^{2}$; and (iii) back-barrier perched lakes that formed in small fluvial valleys by the retention of freshwater and continental sediments induced by sand-barrier blockage. A comparative analysis of nine systems that fit in this broad classification was performed here in order to recognize the regional sedimentary patterns and main changes in sedimentation rates, as well as to identify erosional and non-depositional sedimentary gaps (Fig. 10). These systems include one pocket beach (Seselle; Santos \& Vidal 1994), six estuaries and backbarrier lagoons (Pravia, Miño, Betanzos, Baldaio, Louro and Cíes; Alonso \& Pagés, 2010; Costas et al. 2009: González-Villanueva et al., 2015) and two perched lakes (Traba and Doniños; Bao et al., 2007 ; this work).

Differences in prevailing wind directions, sediment supply, or the sizes of bays and catchments may have contributed to differences in the evolution of these transgressive coastal systems. However, several studies performed on barrier island and non-rocky coastal plain systems have concluded that bedrock topography plays the most significant role (Buynevich \& Fitzgerald, 2003; Looker et al., 2003;

This article is protected by copyright. All rights reserved. 
Tessier et al., 2012; Cooper et al., 2012; Traini et al., 2013; Hein et al., 2014). All of the studied systems herein have significant differences in the elevations of the pre-Holocene bedrock over which the coastal sediments accumulated, which led to differences in the timing of flooding during the Holocene. Pocket beaches developed in the highest elevated coastal sites and were inundated at the end of the HST period (Late Holocene). The ages of these beaches can be estimated by radiocarbon dating the pre-inundation peaty deposits fossilized by beach sand. This is the case for Seselle, which is located at a height of $<6 \mathrm{~m}$ above the bedrock and was flooded by the sea at $3.7 \mathrm{ka}$ cal BP (Fig. 10). In contrast, estuaries and back-barrier lagoon systems, such as Pravia, Miño, Baldaio or Louro, show bedrock surfaces that are always $>20 \mathrm{~m}$ deep and were inundated during the Early and mid-Holocene (Fig. 10). Intermediate substrate depths of more than $17 \mathrm{~m}$ to $6 \mathrm{~m}$ characterize back-barrier perched lakes, such as Doniños and Traba. The barriers and lakes of these systems formed during the midHolocene over older Holocene marine deposits (Doniños) or directly over the bedrock (Traba) (Fig. 10). According to these data, the critical depth of the substrate ranges from $-20 \mathrm{~m}$ to $-17 \mathrm{~m}$ amsl, which constitutes the threshold separating estuaries and back-barrier lagoons from back-barrier perched lakes under the particular Holocene sea-level rise and sediment supply scenario of the northwest coast of the Iberian Peninsula. Cíes represents a special case of a rock-bounded back-barrier lagoon (Costas et al., 2009). It has developed since $3.6 \mathrm{ka}$ cal BP over an elevated freshwater peat that is confined in a bedrock structural basin located at 0 to $-3.5 \mathrm{~m}$ amsl. The present results confirm that antecedent topography is a key controlling factor in the evolution of the systems in the studied region, as has previously been suggested (Bao et al., 2007; Costas et al., 2009). However, comprehensive studies of the potential effects of differences in wind regime, sediment supply, and bay and catchment sizes should be performed.

The three types of coastal systems mentioned above exhibit conspicuous differences in their evolutionary models, as inferred from their observed sedimentary patterns. All estuaries and backbarrier lagoons show characteristic deepening-shallowing upward sequences, despite the fact that, in most cases, data are only available from a single core, precluding the recognition of their twodimensional sedimentary architecture. All of these systems share three main evolutionary phases, with significant changes in sedimentation rates (Fig. 10): (i) during the Early Holocene, shallow marine subtidal and intertidal sediments were deposited at variable sedimentation rates (from 0.6 to $5.1 \mathrm{~mm}$

This article is protected by copyright. All rights reserved. 
$\mathrm{yr}^{-1}$ ), favoured by the accommodation space created during an episode of rapid sea-level rise; (ii) the mid-Holocene stabilization of sea-level led to a scenario of the limited or no creation of accommodation space, in which the estuarine intertidal plains, despite being active, resulted in no sediment accumulation or very low (normally less than $1 \mathrm{~mm} \mathrm{yr}^{-1}$ ) sedimentation rates; and (iii) accelerated rates of sea-level rise during the Late Holocene created new accommodation space, increasing sedimentation rates compared to the previous phase (from 1.2 to $3.1 \mathrm{~mm} \mathrm{yr}^{-1}$ ). In contrast to estuaries and back-barrier lagoons, back-barrier perched lakes, such as Doniños and Traba, constitute peculiar systems that only developed during the Late Holocene. These systems show exclusively continental sedimentation, as well as conspicuous sedimentary gaps between lake sequences that were probably produced by barrier-breaching episodes.

\section{Long-term low-frequency patterns of environmental change in the Doniños back-barrier perched lake}

The sedimentary record of the Doniños coastal system reveals the development of two distinct perched lake environments since ca $4.5 \mathrm{ka}$ cal BP, which are separated by a catastrophic event that occurred sometime between $1.3 \mathrm{ka}$ and $1.1 \mathrm{ka}$ cal BP. Both climatic and non-climatic factors may account for these infrequent but significant environmental changes.

Sedimentological, geochemical and biological data from Unit 5 in core D12-3A characterized the development of a confined lacustrine system between $4.5 \mathrm{ka}$ and $1.3 \mathrm{ka}$ cal BP that was similar to the present-day one, with very limited sea influence restricted to occasional high-energy events during periods of increased storminess. There is no evidence in the Doniños record, at the studied resolution, of higher storminess associated with the Subboreal/Subatlantic transition, as detected in continental shelf records from north-west Spain at ca 2.9 ka cal BP (González-Álvarez et al., 2005). The present study did not find significant water level fluctuations that could be related to the alternation of wet and dry phases in the north-west Iberian Peninsula during this time period (Fábregas-Valcarce et al., 2003; Schellekens et al., 2011; Castro et al., 2015). Instead, diatom assemblages point to progressive water infilling during the deposition of Unit 5. One probable explanation is that, at the low resolution studied in the record here, the occurrence of a very stable sand barrier was the main agent controlling the accumulation of water in the lake and that the variability in precipitation was secondary.

This article is protected by copyright. All rights reserved. 
As mentioned above, a catastrophic episode of lake outflow is the most likely hypothesis to explain the erosive hiatus between Units 5 and 6 (1.3 to $1.1 \mathrm{ka}$ cal BP, Gap-2). Several lines of evidence point to a possible storm surge-induced breaching of the outlet channel at this time. Costas et al. (2012, 2016) identified a pulse of storm-related aeolian activity in the neighbouring coast of Portugal at 1.2 ka cal BP corresponding to the Rapid Climate Change event of 1.0 to $1.2 \mathrm{ka}$ cal BP (Mayewski et al., 2004). Increased storm activity has also been detected in the coastal sedimentary archives of the English Channel and Brittany (north-west France) (Sorrel et al., 2012; Van Vliet-Lanoë et al., 2014a,b) and in the lacustrine records of the Mediterranean Iberian region (Sánchez-López et al., 2016; Corella et al., 2016) at this time interval, which roughly corresponds to the Dark Ages Cold Event (DA)/Medieval Climatic Anomaly (MCA) transition. A combination of high tides and storm surges in the north-east Atlantic under this favourable palaeoclimatic situation could explain the breaching of the outlet channel and the catastrophic erosive event in Doniños. Gap-2 can be correlated with small peaks in marine/brackish diatoms in the back-barrier perched Traba Lake (Bao et al., 2007), which are indicative of higher marine influence at approximately 1.0 to $1.3 \mathrm{ka}$ cal BP in both systems. This time period, however, corresponds to a phase of the stabilization of mean sea-level, aggradation/progradation and reduced marine influence in the Louro back-barrier lagoon (GonzálezVillanueva et al., 2015).

In addition to different sensitivities to the action of wind and swell waves according to the local trend orientation of the coastline, other non-climatic triggers can be invoked to explain the erosive gap. The anthropogenic modification of the barrier is one alternative hypothesis. Significant demographic growth occurred in north-west Spain from the 8th to 14th Centuries, associated with the expansion of agriculture (Guitián Rivera, 2001). Human-induced operations in inlets for sand mining occurred in north-west Spain (Costas et al., 2006) and it has been a common practice to promote the drainage of freshwater accumulated in coastal water bodies to prevent the flooding of adjacent rangelands (España Cantos, 1948; Dalda González 1968; Bao et al., 2007). This use was traditional in the Atlantic coast of the Iberian Peninsula, with the earliest documented record accounting for artificial barrier breaching in Portugal dating back to the end of the 14th Century (Dinis et al., 2006). The available data and the low temporal resolution used in this study do not allow disentanglement of the main causes behind this destructive event.

This article is protected by copyright. All rights reserved. 
A second back-barrier perched lake environment was established after 1.3 to $1.1 \mathrm{ka}$ cal BP and lasted until the present (Unit 6), which spans the onset of the MCA and the development of the Little Ice Age (LIA) and the Industrial Period. The MCA was a relatively humid period in the north-west lberian Peninsula (Moreno et al., 2012, Sánchez-López et al., 2016). The observed increase in elements such as $\mathrm{Fe}$ and $\mathrm{Ti}$ in core $\mathrm{D} 12-3 \mathrm{~A}$ at this time (Fig. 7) is consistent with higher run-off within this more humid scenario. These conditions could explain the observed increase in sedimentation rate in Unit 6, although non-climatic factors should not be ruled out. Extensive human-induced deforestation has existed in the basin since at least the 16th Century, related to both wood exportation and demand by the shipyard of Ferrol (Saavedra, 1991; Santos et al., 2001). Regardless of the cause, increased terrigenous inputs to the coast would have favoured a positive sediment budget and the rapid construction of a new sand barrier with the development of a second back-barrier perched lake after $1.3 \mathrm{ka}$ cal BP (Unit 6). However, this barrier was more permeable to sea influence, as deduced from the high TS content in the sediments of core D12-3A and the diatom assemblages in Unit 6, which suggest times of more saline conditions in the water body than those from the previous perched lake. Both frequent periods of barrier breaching and/or overwash action may account for this enhanced influence of the sea on the system. Most of the sediments of Unit 6 in core D12-3A were deposited during the LIA, a time of intensified storms in the North Atlantic (Trouet et al., 2012), which could account for the higher marine influence, notwithstanding concomitant human-induced operations on the sand barrier. A change in diatom assemblages at the topmost part of Unit 6, reflecting the dominance of freshwater euplanktonic diatoms, suggests a recent origin of the very confined environment typical of the present-day situation. Post-1950 AD wind speed deceleration and decreased storm activity promoted the progressive expansion of vegetation cover in sand barriers of this coast (González-Villanueva et al., 2013). The recent aggradation in the Doniños dune field could therefore explain the strongly reduced permeability of the barrier at present.

\section{CONCLUSIONS}

The formation and evolution of the back-barrier coastal system of Doniños were mainly governed by the antecedent topography and long-term changes in sea-level rise rates during the Holocene transgression, which controlled the accommodation space in the back-barrier area. During the period of rapid sea-level rise (transgressive systems tract, 10.2 to $4.5 \mathrm{ka} \mathrm{BP}$ ), the sea flooded the gently

This article is protected by copyright. All rights reserved. 
sloping coastal ramp, prompting the deposition of marine and, eventually, back-barrier lagoon sediments after the landward migration of a sand barrier. During moderate sea-level rise conditions (highstand systems tract, $4.5 \mathrm{ka}$ BP to today), the growth and closure of the sand barrier favoured the formation of a back-barrier perched lake that stood high above sea-level. Sandy marine and barrier deposits were sourced from the sea, showing accretionary patterns. The fine sediments that accumulated in the lagoon and in the perched lake were mainly fed from the continent. Lacustrine deposits were accumulated following a progradational pattern.

Stratigraphic comparison with other coastal systems in this region (estuaries, back-barrier lagoons, pocket beaches and back-barrier perched lakes) indicates that topographic inheritance is the main factor controlling the final evolutionary stages and, ultimately, the fate of these systems. Bedrock surface heights of $<-20 \mathrm{~m}$ amsl gave rise to intertidal estuarine or back-barrier lagoon environments. Sites with bedrock surfaces between $-20 \mathrm{~m}$ to $-6 \mathrm{~m}$ amsl produced back-barrier freshwater perched lakes. Finally, sandy pocket beaches formed in small coastal bays where the substrate is $>-6 \mathrm{~m}$ amsl.

The evolutionary model of coastal back-barrier perched lakes presented here shows no or very limited marine influence and is mostly dependent on sand barrier stability, which is in turn mainly controlled by sediment budgets, variations in storminess and human-induced operations on the barrier. Natural and artificial barrier breaching can lead to highly destructive erosive episodes promoted by differences in the hydraulic potential of the lake and ocean surfaces. These events are manifested in the sedimentary record by erosive gaps. Notwithstanding this, coastal back-barrier perched lakes are ideal candidates for coastal palaeoclimatic studies; this is due to the stability and continuity of their sedimentation. These lakes constitute excellent alternatives to back-barrier lagoons, which generally display limited accommodation space

This article is protected by copyright. All rights reserved. 


\section{ACKNOWLEDGEMENTS}

This study was funded by the Spanish Ministry of Economy and Competitiveness through the projects CONSOLIDER- Ingenio 2010 GRACCIE (CSD2007-00067), RapidNAO (CGL2013-40608-R) and PaleoMODES (CGL2016-75281-C2-1-R). AH and ML were supported by the Portuguese Science Foundation (FCT) through post-doctoral grants SFRH/BPD/79923/2011 and SFRH/BPD/82103/2011, respectively. $\mathrm{RC}$ is grateful for a PhD fellowship from the Xunta de Galicia (Plan I2C) co-financed by the European Social 94 Fund. Noé Sar contributed to the study of diatom assemblages. Fernando Barreiro (CSIC-IPE) and Olga Margalef (CREAF) collaborated during the coring survey. Special thanks are given to the people of Doniños and José Polo Veiga, from the council of Ferrol, for their assistance during field work. The authors are grateful to Mikkel Fruergaard (University of Copenhagen) and Cesar Andrade (University of Lisbon) for their thorough reviews, which substantially improved the original manuscript.

\section{REFERENCES}

Alonso, A. and Pagés, J.L. (2007) Stratigraphy of Late Pleistocene coastal deposits in Northern Spain. Journal of Iberian Geology, 33, 207-220.

Alonso, A. and Pagés, J.L. (2010) Evolución del nivel del mar durante el Holoceno en el noroeste de la Península Ibérica. Rev. Soc. Geol. Esp., 23, 157-167.

Andrade, C., Freitas, M.C., Moreno, J. and Craveiro, S.C. (2004) Stratigraphical evidence of Late Holocene barrier breaching and extreme storms in lagoonal sediments of Ría Formosa, Algarve, Portugal. Mar. Geol., 210, 339-362.

Arribas, J., Alonso, A., and Pagés, J.L. and González-Acebrón, L. (2010) Holocene transgression recorded by sand composition in the mesotidal Galician coastline (NW Spain). Holocene, 20, 375-393.

Bao, R., Alonso, A., Delgado, C. and Pagés, J.L. (2007) Identification of the main driving mechanisms in the evolution of a small coastal wetland (Traba, Galicia, NW Spain) since its origin 5700 cal yr BP. Palaeogeogr. Palaeoclimatol. Palaeoecol., 247, 296-312.

This article is protected by copyright. All rights reserved. 
Bao, R., Varela, M. and Prego, R. (1997) Mesoscale distribution patterns of diatoms in surface sediments as tracers of coastal upwelling of the Galician shelf (NW Iberian Peninsula). Mar. Geol., 144, 117-130.

Blanco-Chao, R., Costa-Cascais, M., Martinez-Cortizas, A. and Pérez-Alberti, A. (2003) Evolution and inheritance of a rock coast: Western Galicia, Northwestern Spain. Earth Surf. Process. Landforms, 28, 757-775.

Boyd, R., Dalrymple, R. and Zaitlin, B.A. (1992) Classification of clastic coastal depositional environments. Sed. Geol., 80, 139-150.

Buynevich, I.V. and Fitzgerald, D.M. (2003) High-resolution subsurface (gpr) imaging and sedimentology of coastal ponds, Maine, U.S.A.: implications for holocene back-barrier evolution. J. Sed. Res., 73, 559-571.

Carrasco, A.R., Ferreira, Ó. and Roelvink, D. (2016) Coastal lagoons and rising sea level: A review. Earth-Sci. Rev., 154, 356-368

Castro, D., Souto, M., Garcia-Rodeja, E., Pontevedra-Pombal, X. and Fraga, M.I. (2015) Climate change records between the mid- and late Holocene in a peat bog from Serra do Xistral (SW Europe) using plant macrofossils and peat humification analyses. Palaeogeogr. Palaeoclimatol. Palaeoecol., 420, 82-95.

Cattaneo, A. and Steel, R.J. (2003) Transgressive deposits: a review of their variability. Earth-Sci. Rev., 62, 187228.

Chaumillon, E., Bertin, X., Fortunato, André B., Bajo, M., Schneider, J. L., Dezileau, L., Walsh, J.P., Michelot, A., Chauveau, E., Créach, A., Hénaff, A., Sauzeau, T., Waeles, B., Gervais, B., Jan, G., Baumann, J., Breilh, J.-F. and Pedreros, R. (2017) Storm-induced marine flooding: Lessons from a multidisciplinary approach. Earth-Sci. Rev., 165, 151-184.

Chung, F.H. (1974a) Quantitative interpretation of X-ray diffraction patterns of mixtures. I. Matrixflushing method for quantitative multicomponent analysis. J. Appl. Crystallogr., 7, 519-525.

Chung, F.H. (1974b) Quantitative interpretation of X-ray diffraction patterns of mixtures. II. Adiabatic principle of X-ray diffraction analysis of mixtures. J. Appl. Crystallogr., 7, 526-531.

This article is protected by copyright. All rights reserved. 
Cooper, J.A.G., Jackson, D.W.T., Dawson, A.G., Dawson, S., Bates, C.R. and Ritchie, W. (2012) Barrier islands on bedrock: A new landform type demonstrating the role of antecedent topography on barrier form and evolution. Geology, 40, 923-926.

Corella. J. P., Valero-Garcés. B. L., Vicente- Serrano. S. M., Brauer. A. and Benito, G. (2016) Three millennia of heavy rainfalls in Western Mediterranean: frequency, seasonality and atmospheric driver. Scientific Reports, 6 , 38206.

Costas, S., Alejo, I., Rial, F., Lorenzo, H. and Nombela, M.A. (2006) Cyclical evolution of a modern transgressive sand barrier in NW-Spain elucidated by GPR and aerial photo. J. Sed. Res., 76, 1077-1092.

Costas, S., Jerez, S., Trigo, R.M., Goble, R. and Rebêlo, L. (2012) Sand invasion along the Portuguese coast forced by westerly shifts during cold climate events. Quatern. Sci. Rev., 42, 15-28.

Costas, S., Muñoz-Sobrino, C., Alejo, I. and Pérez-Arlucea, M. (2009) Holocene evolution of a rock-bounded barrier-lagoon system, Cíes Islands, northwest Iberia. Earth Surf. Proc. Land., 34, 1575-1586.

Costas, S., Naughton, F., Goble, R. and Renssen, H. (2016) Windiness spells in SW Europe since the last glacial maximum. Earth Planet. Sci. Lett., 436, 82-92.

Curray, J.R. (1964) Transgressions and regressions. In: Papers in Marine Geology (Ed R.L. Miller), pp. 175-203. MacMillan, New York.

Dalda González, J. (1968) Estudio fitoecológico de la laguna de Valdoviño, en La Coruña. Botanica Complutensis, 1, 15-50.

Day, J., Christian, R., Boesch, D., Yáñez-Arancibia, A., Morris, J., Twilley, R., Naylor, L., Schaffner, L. and Stevenson, C. (2008) Consequences of Climate Change on the Ecogeomorphology of Coastal Wetlands. Estuaries and Coasts, 31, 477-491.

Devoy, R.J.N., Delaney, C., Carter, R.W.G. and Jennings, S.C. (1996) Coastal stratigraphies as indicators of environmental changes upon European Atlantic Coasts in the late Holocene. J. Coastal Res., 12, 564-588.

Dinis, J.L., Henriques, V., Freitas, M.C., Andrade, C. and Costa, P. (2006) Natural to anthropogenic forcing in the Holocene evolution of three coastal lagoons (Caldas da Rainha valley, western Portugal). Quatern. Int., 150, 41-51.

This article is protected by copyright. All rights reserved. 
Díez Montes, A., González Menendez, L., Matínez Catalán, J.R. and Gallastegui, G. (2017) Mapa Geológico Digital continuo 1:50.000, Zona Galicia Trás-os-Montes (zona 1200). In GEODE. http://info.igme.es/cartografiadigital/geologica/geozona.aspx?ld=1200

España Cantos, J. (1948) Un día a las acuáticas en el lago de Valdoviño. Calendario mensual ilustrado de caza y pesca fluvial y marítima, armas y guardería, VI, 137-141.

Fábregas-Valcarce, R., Martínez Cortizas, A., Blanco Chao, R. and Chesworth, W. (2003) Environmental change and social dynamics in the second-third millenium BC in NW Iberia. J. Archaeol. Sci., 30, 859-871.

Fernández-López, I. (1998) Estudio xeomorfolóxico da pequena dorsal de Ferrol e o seu contorno. Memoria de Licenciatura inédita. Dpto. Xeografía, Universidade de Santiago de Compostela.

Fruergaard, M., Andersen, T.J., Nielsen, L.H., Johannessen, P.N., Aagaard, T. and Pejrup, M. (2015a) Highresolution reconstruction of a coastal barrier system: Impact of Holocene sea-level change. Sedimentology, $\mathbf{6 2}$, 928-969.

Fruergaard, M., Møller, I., Johannessen, P.N., Nielsen, L.H., Andersen, T.J., Nielsen, L., Sander, L. and Pejrup, M. (2015b) Stratigraphy, evolution, and controls of a Holocene transgressive-regressive barrier island under changing sea level: Danish North Sea coast. J. Sed. Res., 85, 820-844

Fruergaard, M., Andersen, T.J., Nielsen, L.H., Madsen, A.T., Johannessen, P.N., Murray, A.S., Kirkegaard,L. and Pejrup, M. (2011) Punctuated sediment record resulting from channel migration in a shallow sand dominated micro-tidal lagoon, Northern Wadden Sea, Denmark. Mar. Geol., 280, 91-104.

González-Álvarez, R., Bernárdez, P., Pena, L.D., Francés, G., Prego, R., Diz, P. and Vilas, F. (2005) Paleoclimatic evolution of the Galician continental shelf (NW of Spain) during the last 3000 years: from a storm regime to present conditions. Journal of Marine Systems, 54, 245-260.

González-Villanueva, R., Costas, S., Pérez-Arlucea, M., Jerez, S. and Trigo, R.M. (2013) Impact of atmospheric circulation patterns on coastal dune dynamics, NW Spain. Geomorphology, 185, 96-109. González-Villanueva, R., Pérez-Arlucea, M., Costas, S., Bao, R., Otero, X.L. and Goble, R. (2015) 8000 years of environmental evolution of barrier -lagoon systems emplaced in coastal embayments (NW Iberia). Holocene, 25, 1-16.

This article is protected by copyright. All rights reserved. 
Gregory, B.R.B., Peros, M., Reinhardt, E.G. and Donnelly, J.P. (2015) Middle-late Holocene Caribbean aridity inferred from foraminifera and elemental data in sediment cores from two Cuban lagoons. Palaeogeogr. Palaeoclimatol. Palaeoecol., 426, 229-241.

Guitán-Rivera, L. (2001) La destrucción histórica del bosque en Galicia. SÉMATA, Ciencias Sociais e Humanidades, 13, 105-166.

Harrison F.W. (1988) Utilization of freshwater sponges in paleolimnological studies. Palaeogeogr. Palaeoclimatol. Palaeoecol., 62, 387-397.

Hein, C.J., Fitzgerald, D.M., Menezes, J.T., Cleary, W.J., Klein, A.H. and Albernaz, M.B. (2014) Coastal response to late-stage transgression and sea-level highstand. Geol. Soc. Am. Bull., 126, 459-480

Hein, C.J., Fitzgerald, D.M., De Souza, L.H., Georgiou, J.Y., Buynevich, I.V., Klein, A.H., De Menezes, J.T., Cleary, W.J. and Scolaro, T.L. (2016) Complex coastal change in response to autogenic basin infilling: An example from a sub-tropical Holocene strandplain. Sedimentology, 63, 1362-1395.

Jackson, D.W.T. and Cooper, J.A.G. (2011) Coastal dune fields in Ireland: rapid regional response to climatic change. J. Coastal Res., S164, 293-297.

Kamatani, A. and Oku, O. (2000) Measuring biogenic silica in marine sediments. Mar. Chem., 68, 219-229.

Kempf, P., Moernaut, J., Van Daele, M., Vandoorne, W., Pino, M., Urrutia, R. and De Batist, M. (2017) Coastal lake sediments reveal 5500 years of tsunami history in south central Chile. Quatern. Sci. Rev., 161, 99116.

Lambeck, K., Yokoyama, Y. and Purcell, T. (2002) Into and out of the Last Glacial Maximum: sea-level change during Oxygen Isotope Stages 3 and 2. Quatern. Sci. Rev., 21, 343-360.

Lee, T.F. and Eggleston, P.M. (1989) Airborne algae and cyanobacteria. Grana, 28, 63-66.

Leorri, E., Fatela, F., Drago, T., Bradley, S.L., Moreno, J. and Cearreta, A. (2012) Lateglacial and Holocene coastal evolution in the Minho estuary (N Portugal): Implications for understanding sea-level changes in Atlantic Iberia. Holocene, 76, 46-57.

This article is protected by copyright. All rights reserved. 
Liu, K.B. (2007) Paleotempestology, In: Elias, S.A. (Ed.), The Encyclopedia of Quaternary Scienc. Elsevier, pp. 1974-1985.

Locker, S.D., Hine, A.C. and Brooks, G.R. (2003) Regional stratigraphic framework linking continental shelf and coastal sedimentary deposits of west-central Florida. Mar. Geol., 200, 351-378.

López-Cancelo, L. (2004) Cambios paleoambientales en el NW Peninsular durante el Holoceno determinados a partir del estudio de foraminíferos bentónicos". Ph Thesis, Universidade da Coruña. 195 pp.

Lorenzo, F., Alonso, A. and Pagés, J.L. (2007) Erosion and accretion of Beach/spit systems in Northwest Spain: A response to human activity. J. Coastal Res., 23, 834-845.

Lozano, I., Devoy, R.J.N., May, W. and Andersen, U. (2004) Storminess and vulnerability along the Atlantic coastlines of Europe: analysis of storm records and of greenhouse gases induced climate scenario. Mar. Geol., 210, 205-225.

McQuoid, M.R. and Hobson. L.A. (1998) Assessment of palaeoenvironmental conditions on Southern Vancouver Island, British Columbia, Canada, using the marine tychopankter Paralia sulcata. Diatom. Res., 13, $311-321$

Marcos, M. and Amores, A. (2014) Quantifying anthropogenic and natural contributions to thermosteric sea level rise. Geophys. Res. Lett., 41, 2502-2507.

Martínez-Carreño, N., García-Gil, S. and Cartelle, V. (2017) An unusual Holocene fan-shaped subaqueous prograding body at the back of the Cíes Islands ridge (Ría de Vigo, NW Spain): Geomorphology, facies and stratigraphic architecture. Mar. Geol., 385, 13-26.

Martínez-Carreño, N. and García-Gil, S. (2017) Reinterpretation of the Quaternary sedimentary infill of the Ría de Vigo, NW Iberian Peninsula, as a compound incised valley. Quatern. Sci. Rev., 173, 124-144.

Massey, A. C. and Taylor, G. K. (2007) Coastal evolution in south-west England, United Kingdom: An enhanced reconstruction using geophysical surveys. Mar. Geol., 245, 123-140.

This article is protected by copyright. All rights reserved. 
Mayewski, P.A., Rohling, E.E., Stager, J.C., Karlén, W., Maasch, K.A., Meeker, L.D., Meyerson, E.A., Gasse, F., van Kreveld, S., Holmgrem, K., Lee-Thorp, J., Rosqvist, G., Rack, F., Staubwasser, M., Schneider, R.R. and Steig, E.J. (2004) Holocene climate variability. Quatern. Res., 62, 243-255.

Melo, S., Torgan, L.C., Menezes, M., Huszar, V.L.M., Corréa, J.D. and Bozelii, R.L. (2003) Taxonomy and ecology of Synedropsis roundii sp. nov. (Bacillariophyta) from a tropical brackish coastal lagoon, south-eastern Brazil. Phycologia, 42, 71-79.

Moreno, A., Pérez, A., Frigola, J., Nieto-Moreno, V., Rodrigo-Gámiz, M., González-Sampériz, P., Morellón, M., Martín-Puertas, C., Corella, J. P., Belmonte, A.,Sancho, C., Cacho, I., Herrera, G., Canals, M., JiménezEspejo, F., Martínez-Ruiz, F., Vegas, T. and Valero-Garcés, B.L. (2012) The Medieval Climate Anomaly in the Iberian Peninsula reconstructed from marine and lake records. Quatern. Sci. Rev., 43, 16-32.

Mosquera-Santé, M.J. (2001) Evolución postglacial del nivel del mar en el NW de la Península Ibérica. El caso del Golfo Artabro (A Coruña, Galicia, España). Ph Thesis, Universidade da Coruña, 155 pp.

Niedoroda, A.W., Swift, D.J.P., Figueiredo, A.G. and Freeland, G.L. (1985) Barrier island evolution, middle Atlantic shelf, U.S.A. Part II: Evidence from the shelf floor. Mar. Geol., 63, 363-396.

Orme, L.C., Charman, D.J., Reinhardt, L., Jones, R.T., Mitchell, F.J.G., Stefanini, B.S., Barkwith, A., Ellis,M.A. and Grosvenor, M. (2017) Past changes in the North Atlantic storm track driven by insolation and sea-ice forcing. Geology, 45, 335-338.

Pérez-Arlucea, M., Almécija, C., González-Villanueva, R. and Alejo, I. (2011) Water dynamics in a barrierlagoon system: controlling factors. J. Coastal Res., 64, 15-19.

Reimer, P.J., Bard, E., Bayliss, A., Beck, J.W., Blackwell, P.G., Ramsey, C.B., Buck, C.E., Cheng, H., Edwards, R.L., Friedrich, M., Grootes, P.M., Guilderson, T.P., Haflidason H., Hajdas, I., Hatté, C., Heaton, T.J., Hoffmann, D.L., Hogg, A.G., Hughen, K.A., Kaise,r K.F., Kromer, B., Manning, S.W., Niu, M., Reimer, R.W., Richards, D.A., Scott, E.M., Southon, J.R., Staff, R.A., Turney, C.S.M. and van der Plicht, J. (2013) IntCal13 and Marine13 Radiocarbon Age Calibration Curves 0-50,000 Years cal BP. Radiocarbon, 55,1869-1887 Renberg, I. (1990) A procedure for preparing large sets of diatom slides from sediment cores. J. Paleolimnol., 4, 87-90.

This article is protected by copyright. All rights reserved. 
Rey, D., Alvarez-Iglesias, P. Araujo, M.F., Bernabeu, A. M., Comas, M., Decastro, M., Druet, M., Ferreira Da Silva, E., Ferrín, A., Gesteira, M., Martins, V., Mohamed, K.J., Rubio, B. and Vilas F. (2014) The NW Iberian continental shelf. In: Chiocci, F. L. \& Chivas, A. R. (eds) Continental Shelves of the World: Their Evolution during the Last Glacio-Eustatic Cycle. Geological Society, London, Memoirs, 41, 91-108.

Riggs, S.R., Cleary W.J. and Snyder, S.W. (1995) Influence of inherited geologic framework on barrier shoreface morphology and dynamics. Mar. Geol., 126, 213-234

Roy, P., Cowell, P., Ferland, M. and Thom, B. (1995) Wave-dominated coasts. In R. Carter \& C. Woodroffe (Eds.), Coastal Evolution: Late Quaternary Shoreline Morphodynamics. Cambridge University Press. Cambridge, pp. 121-186.

Saavedra, P., 1991. A Galicia do antigo réxime. Economía e sociedade. Proxecto Galicia-Historia, volume III. Ed. Hércules, A Coruña.

Sancetta, C. (1979) Use of semiquantitative microfossil data for paleoceanography. Geology, 7, 88-92.

Sánchez-López, G., Hernández, A., Pla-Rabes, S., Trigo, R.M., Toro, M., Granados, I., Sáez, A., Masqué, P., Pueyo, J.J., Rubio-Inglés, M.J. and Giralt, S. (2016) Climate reconstruction for the last two millennia in central Iberia: the role of East Atlantic (EA), North Atlantic Oscillation (NAO) and their interplay over the Iberian peninsula. Quatern. Sci. Rev. 149, 135-150.

Santos, L., Bao, R. and Sanchez Goñi, M.F. (2001) Pollen record of the last 500 years from the Doniños coastal lagoon (NW Iberian Peninsula): changes in the pollinic catchment size versus paleoecological interpretation. J. Coastal Res., 17, 705-713.

Santos, L. and Vidal, J.R. (1993) El lagoon de Seselle: Un episodio de la transgresión holocena en la Ría de Ares (A Coruña, España). Cadernos Lab. Xeol. Laxe, 18, 163-174.

Schellekens, J., Buurman, P., Fraga, I. and Martínez-Cortizas, A. (2011) Holocene vegetation and hydrologic changes inferred from molecular vegetation markers in peat, Penido Vello (Galicia, Spain). Palaeogeogr. Palaeoclimatol. Palaeoecol., 299, 56-69.

This article is protected by copyright. All rights reserved. 
Sorrel, P., Debret, M., Billeaud, I., Jaccard, S.L., McManus, J.F. and Tessier, B. (2012) Persistent non-solar forcing of Holocene storm dynamics in coastal sedimentary archives. Nature Geosc., 5, 892-896.

Stuiver, M. and Reimer, P.J. (1993) Extended C-14 data base and revised Calib 3.0 C-14 age calibration program. Radiocarbon, 35, 215-230.

Tessier, B., Billeaud, I., Sorrel, P., Delsinne, N. and Lesueur, P. (2012) Infilling stratigraphy of macrotidal tidedominated estuaries. Controlling mechanisms: sea-level fluctuations, bedrock morphology, sediment supply and climate changes (The examples of the Seine estuary and the Mont-Saint-Michel Bay, English Channel, NW France). Sed. Geol., 279, 62-73.

Tesson, M., Labaune, C., Gensous, B., Suc, J.P., Melinte-Dobrinescu, M., Parize, O., Imbert, P. and Delhaye-Prat, V. (2011) Quaternary “compound” incised valley in a microtidal environment, Roussillon continental shelf, western Gulf of Lions, France. J. Sed. Res., 81, 708-729.

Traini, C., Menier, D., Proust, J.-N. and Sorrel, P. (2013) Transgressive systems tract of a ria-type estuary: The Late Holocene Vilaine River drowned valley (France). Mar. Geol., 337, 140-155.

Trouet, V., Scourse, J.D. and Raible, C.C. (2012) North Atlantic storminess and Atlantic Meridional Overturning Circulation during the last Millennium: Reconciling contradictory proxy records of NAO variability. Global Planet. Change, 84, 48-55.

Van Vliet-Lanoë, B., Goslin, J., Hallegouët, B., Hénaff, A., Delacourt, C., Fernane, A., Franzetti, M.A., Le Cornec, E. and Le Roy, P. (2014a) Middle to Late Holocene storminess in Brittany (NW France). Part I: morphological impact and stratigraphical record. Holocene, 24, 413-433.

Van Vliet-Lanoë, B., Penaud, A., Hénaff, A., Delacourt, C., Fernane, A., Goslin, J., Hallegouët, B. and Band Le Cornec, E. (2014b) Middle to Late Holocene storminess in Brittany (NW France). Part II: the chronology of events and climate forcing. Holocene, 24, 434-453.

Vilas, F. and Rolán, E. (1985) Caracterización de las lagunas costeras de Galicia, N.W. Peninsula Ibérica. España. Actas I Congreso Ibérico de Quaternario. Universidade de Lisboa. Lisboa, pp. 253-268.

Vos, P.C. and De Wolf, H. (1993) Diatoms as a tool for reconstructing sedimentary environments in coastal wetlands: methodological aspects. Hydrobiologia, 269/270, 285-296.

This article is protected by copyright. All rights reserved. 
Wolin, J.A. and Stone, J.R. (2010) Diatoms as indicators of water-level change in freshwater lakes, In: Smol, J.P., Stoermer, E.F. (Eds.), The Diatoms: Applications for the Environmental and Earth Sciences. Cambridge University Press, Cambridge, pp. 174-185.

Zong, Y. (1997) Implications of Paralia sulcata abundance in Scottish isolation basins. Diatom Research, 12, $125-150$

\section{FIGURE CAPTIONS}

Fig. 1. A. Map of south-west Europe showing the location of the north-west coast of the lberian Peninsula (red area). B. Map of north-west Spain showing the coastal sites discussed in this study (1. Pravia; 2. Doniños; 3. Seselle; 4. Miño; 5. Betanzos; 6. Baldaio; 7. Traba; 8. Louro; 9. Cíes). Main rivers leading to estuaries in the rías are included in blue. Note the small size of fluvial systems associated with the Doniños and Traba back-barrier perched-lake systems. C. Geological map of the Doniños coastal system and the O Regueiro river catchment (adapted from Díez Montes et al., 2017) showing the main morphological and hydrological elements and the offshore core from the open bay (C29). D. Satellite image of the Doniños zone showing a transect of the studied cores located in the aeolian barrier and lake that are included in the cross-section of Fig. 4. Image from Google Earth ${ }^{\mathrm{TM}}$.

Fig. 2. A. Broad view aerial photograph of the Doniños coastal system showing the embayment and the extent of the catchment (limited by the yellow dotted line) of the O Regueiro River. B. Aerial photograph of the Doniños coastal system with the main geomorphological units.

Fig. 3. Sea-level change over the last $12 \mathrm{ka}$ constructed from core data of 40 coastal systems in north-west Spain (modified from Alonso \& Pagés, 2010). Values of sea-level rise rates by periods are

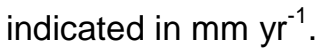

Fig. 4. Stratigraphic west-east cross-section of the Doniños coastal system. Lithological units, main stratigraphic surfaces and radiocarbon ages in cores are indicated. White circles in logs indicate age control levels. Red rectangles indicate locations of photographs in Fig. 5.

This article is protected by copyright. All rights reserved. 
Fig. 5. Photographs of main lithofacies of Doniños Lake. Dotted lines indicate erosive surfaces. A. Lower part of core D12-2B showing an erosive contact between pedogenized bedrock of Unit S (Facies Bra) and texturally mature white aeolian sands (Eo) of Unit 1. Arrow indicates palaeosol with carbonized plant remains. B. Lower part of core D12-3A showing an erosive contact between bioclastic marine sands of Unit $2(\mathrm{Ma})$ and dark muds of lagoonal facies of Unit $3(\mathrm{Lg})$. C. Upper part of core D12-3A showing massive dark mud corresponding to lacustrine facies (Lks) of Unit 6.

Fig. 6. Graphic showing sedimentation rate (SR) variations of lithological units in core D12-3A. Sedimentary gap intervals are indicated in grey. Rates of sea-level rise (SLR) during different intervals are also indicated. Note that the highest SR values correspond to intervals during moderate SLR when perched lake sedimentation occurred.

Fig. 7. Sedimentary rate (average by units), geochemical and mineralogical compositions of core D12-3A from X-ray fluorescence (XRF) and X-ray diffraction (XRD) analyses. Only those elements and minerals with palaeoenvironmental significance are represented. Lithological units and Diatom Assemblage Zones are also indicated.

Fig. 8. A. Sea-level variations for the north-west coast of Spain (Alonso \& Pagés, 2010). Roman numerals indicate the main sedimentological events and palaeogeographical stages (Fig.9) in the Doniños coastal system. B. Time-stratigraphy of the Doniños coastal system showing intervals of sedimentation and gaps correlated with the sea-level curve. White circles in logs indicate age control levels. Note the correspondence between the younger component of Gap 1 and the stabilization of sea-level during the mid-Holocene period.

Fig. 9. Left panel: Palaeogeographic reconstruction maps of main phases of sedimentary evolution of the Doniños coastal system over the last $10 \mathrm{ka}$. Right panel: schematic west-east cross-sections of the depositional units of the Doniños system and active erosive surfaces for each phase (not to scale). The phase age limits are indicated in the sea-level curve of Fig. 8A.

This article is protected by copyright. All rights reserved. 
Fig. 10. Compilation of selected Holocene records from pocket beaches, estuaries, back-barrierlagoons and back-barrier perched lakes in north-west lberia. Site locations are shown in Fig. 1A. Source data from Seselle in Santos \& Vidal (1993); Traba (core TR1) in Bao et al. (2007); Doniños (core D12-3A) in this study; estuaries or back-barrier lagoons of Pravia, Miño, Betanzos and Baldaio (single cores) in Alonso \& Pagés (2010); Louro (composite of cores TL3L7, TL4L1, TL4L13, TL4L18, T6L4 and T6L17) in González-Villanueva et al. (2015). Black circles correspond to control age samples. Brown bars correspond to lacustrine sedimentation intervals, blue bars correspond to marine (lagoon and beach) sedimentation and red dotted lines correspond to low or null sedimentation rates. Numbers above bars and lines correspond to calculated average sedimentation rates (SRs) of the interval $\left(\mathrm{mm} \mathrm{yr}^{-1}\right)$. Note the low SRs in all records during the mid-Holocene and Late Holocene in perched lakes.

\section{TABLE CAPTIONS}

Table 1. The AMS radiocarbon ages of pollen-enriched extracts from samples of cores D12-1B, D12$3 A$ and D12-4A analysed in this study. The table also includes age data of organic sediments from cores obtained by López-Cancelo (2004) and Santos et al. (2001), as well as foraminifera carbonate shells from Mosquera-Santé (2001). Asterisks correspond to samples with ages not used in the chronostratigraphic framework.

Table 2. Textural, mineralogical, geochemical, diatom and sponge contents and palaeoenvironmental interpretations of the different facies and units of the Doniños coastal system. Data from cored deposits and present-day analogues (i.e. surface sediments) are shown for comparison.

This article is protected by copyright. All rights reserved. 


\begin{tabular}{|c|c|c|c|c|c|c|c|c|c|c|c|}
\hline $\begin{array}{l}\text { Sample } \\
\text { number }\end{array}$ & Facies & Unit & $\begin{array}{c}\text { Core depth } \\
(\mathrm{cm})\end{array}$ & $\begin{array}{c}\text { Depth } \\
(m, \text { amsl) }\end{array}$ & Sample name & Dated material & Lab. no. & $\operatorname{Age}^{14} \mathrm{C}$ & $\begin{array}{c}\text { Calibrated } \\
\text { age (years } \\
\text { BP) }\end{array}$ & $\begin{array}{c}2 \sigma(c a l . \\
y r B P)\end{array}$ & $\begin{array}{l}\text { Sedimentary } \\
\text { enviornment }\end{array}$ \\
\hline \multicolumn{12}{|c|}{ ORE D12-1B (this work), lake level $5 \mathrm{~m}$ amsl, lake depth $9.20 \mathrm{~m}$} \\
\hline 1 & Dark mud & 6 & 20 & -4.4 & DON-1B-1-20 & Pollen-enriched extract & ULA-6175 & $380 \pm 20 \mathrm{BP}$ & 464 & $-35 / 39$ & Perched lake 2 \\
\hline 2 & Dark mud & 6 & 40 & -4.6 & DON-1B-1-40 & Pollen-enriched extract & ULA-6176 & $545 \pm 20 \mathrm{BP}$ & 546 & $-24 / 12$ & Perched lake 2 \\
\hline 3 & Dark mud & 6 & 80 & -5.0 & DON-1B-1-80 & Pollen-enriched extract & ULA-6170 & $565 \pm 20 \mathrm{BP}$ & 602 & $-7 / 33$ & Perched lake 2 \\
\hline 4 & Dark mud & 6 & 120 & -5.4 & DON-1B-1-120 & Pollen-enriched extract & ULA-6171 & $705 \pm 20 \mathrm{BP}$ & 668 & $-16 / 16$ & Perched lake 2 \\
\hline 5 & Dark mud & 5 & 135 & -5.6 & DON-1B-1-135* & Pollen-enriched extract & ULA-6174 & $2500 \pm 20 \mathrm{BP}$ & $2581^{\star}$ & $30 / 22$ & Perched lake 1 \\
\hline 6 & Dark mud & 5 & 155 & -5.8 & DON 1B-2-20 & Pollen-enriched extract & ULA-6178 & $1470 \pm 20 \mathrm{BP}$ & 135 & $44 / 37$ & Perched lake 1 \\
\hline 7 & Dark mud & 5 & 215 & -6.4 & DON 1B-2-80 & Pollen-enriched extract & ULA-6177 & $1855 \pm 20 \mathrm{BP}$ & 1788 & $-48 / 38$ & Perched lake 1 \\
\hline 8 & Dark mud & 5 & 307 & -7.3 & DON 1B-3-25 & Pollen-enriched extract & ULA-6172 & $7285 \pm 20 \mathrm{BP}$ & 8104 & $-76 / 61$ & Perched lake 1 \\
\hline 9 & Dark mud & 2 & 322 & -7.4 & DON 1B-3-40 & Pollen-enriched extract & \begin{tabular}{ll|} 
ULA-6173 \\
\end{tabular} & $7584 \pm 30 \mathrm{BP}$ & 8101 & $-22 / 68$ & Shoreface-foreshore \\
\hline \multicolumn{12}{|c|}{ CORE D12-2B (this work), lake level $5 \mathrm{~m}$ amst } \\
\hline 38 & Carbonized root & $\mathrm{s}$ & 360 & -7.1 & DON 2B-3-86 & Organic sediment & ULA-6639 & $9045 \pm 25 \mathrm{BP}$ & 10219 & $-27 / 21$ & Pre-inundation soil \\
\hline 39 & Carbonized root & $\mathrm{s}$ & 360 & -7.1 & DON 2B-3-10 & Organic sediment & ULA-6640 & $9020 \pm 25 \mathrm{BP}$ & 10210 & $-18 / 22$ & Pre-inundation soil \\
\hline \multicolumn{12}{|c|}{ CORE D12-3A (this work), lake level $5 \mathrm{~m}$ amsl, lake depth $9.20 \mathrm{~m}$} \\
\hline 10 & Dark mud & 6 & 10 & -4.3 & DON-3A-1-10 & Pollen-enriched extract & 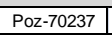 & $110.25 \pm 0.36 \mathrm{pMC}$ & -47 & & Perched lake 2 \\
\hline 11 & Dark mud & 6 & 20 & -4.4 & DON-3A-1-20 & Pollen-enriched extract & ULA-6014 & $490 \pm 25 \mathrm{BP}$ & 523 & $-18 / 17$ & Perched lake 2 \\
\hline 12 & Dark mud & 6 & 36 & & DON-3A-1-36 & Pollen-enriched extract & ULA-6015 & & & $-24 / 47$ & Perched lake 2 \\
\hline 13 & & 6 & 50 & -4.7 & & & & & & & \\
\hline 14 & Dark mud & 6 & 98 & -5.2 & DON-3A-1. & & & & & & Perched lake 2 \\
\hline 15 & Dark mud & 6 & 146 & -5.7 & DON-3A-1-146 & Pollen-enriched extract & Poz-70238 & $630 \pm 30 \mathrm{BP}$ & 600 & $-48 / 13$ & Perched lake 2 \\
\hline 16 & Dark mud & 6 & 164 & -5.8 & DON-3A-1-164 & Pollen-enriched extract & \begin{tabular}{|l|l|} 
Poz-70239 \\
\end{tabular} & $775 \pm 30 \mathrm{BP}$ & 700 & $-31 / 35$ & Perched lake 2 \\
\hline 17 & & 5 & & & DON-3A-2-6 & Pollen-enriched extract & ULA-5710 & & & & \\
\hline 18 & Dark mud & 5 & 210 & -6.3 & & & & & & & Perched lake 1 \\
\hline 19 & Dark mud & 5 & 222.4 & -6.4 & N-3A-2-58 & Pollen-enriched extract & \begin{tabular}{|l|} 
Poz-70241 \\
\end{tabular} & $2705 \pm 30 \mathrm{BP}$ & 2804 & 87151 & Perched lake 1 \\
\hline 20 & Dark mud & 5 & 286.4 & 1. & DON-3A-2-122 & Pollen-enriched extract & \begin{tabular}{|l|l|} 
Poz-70243 \\
\end{tabular} & $3180 \pm 35 \mathrm{BP}$ & 3406 & $-62 / 64$ & Perched lake 1 \\
\hline 21 & Dark mud & 5 & & & DON-3A-2-153 & Pollen-enriched extract & \begin{tabular}{|l|l|} 
Poz-70244 \\
\end{tabular} & $3415 \pm 35 \mathrm{BP}$ & & $-91 / 62$ & Perched lake 1 \\
\hline 22 & $\mathrm{Da}$ & 3 & & & DON-3A-3su & Pollen-enriched extract & ULA-5709 $>2$ C & & & $-24 / 34$ & Lagoon \\
\hline 23 & & 3 & & & & & & & & & \\
\hline 24 & Dark mud & 3 & 36 & -7.8 & & & Poz-7 & & & & Lagoon \\
\hline 25 & Dark mud & 3 & 37 & -7.9 & DON. & Pollen-enriched extract & Poz-70246 & $50 \mathrm{BP}$ & 845 & & Lagoon \\
\hline 26 & Dark mu & 3 & & & & dextract & Poz-7 & & & & Lago \\
\hline 27 & Green bioclastic sand & 2 & 395 & -8.2 & & Pollen-enriched extract & \begin{tabular}{|l|} 
ULA-A 5720 \\
\end{tabular} & & & $-63 / 102$ & Shoreface-foreshore \\
\hline 28 & Green bioclastic sand & 2 & 425.2 & -8.5 & DON-3A-3inf-42 & Pollen-enriched extract & \begin{tabular}{|l|} 
Poz-70249 \\
\end{tabular} & $8150 \pm 50 \mathrm{BP}$ & 9094 & $-90 / 162$ & Shoreface-foreshore \\
\hline \multicolumn{12}{|c|}{ CORE D12-4A (this work), lake level $5 \mathrm{~m}$ amsl, lake depth $5.25 \mathrm{~m}$} \\
\hline 29 & Dark mud & 6 & 20 & -0.5 & & Pollen-enriched extract & & $910 \pm 20 \mathrm{BP}$ & & $-76 / 56$ & ned lake 2 \\
\hline 30 & Dark mud & 6 & 50 & -0.8 & DON-4A-1-50 & Pollen-enriched extract & ULA-6133 & $885 \pm 15 \mathrm{BP}$ & & 3 & ke 2 \\
\hline 31 & & 6 & 90 & & & Pollen-enriched extract & ULA-6134 & & & & \\
\hline 32 & & 6 & & & & Pollen-e & & & & $-57 / 53$ & Perched lake 2 \\
\hline 33 & Dark mud & 6 & & -1 & DON 4A-1-155 & Pollen-enriched extract & ULA-6136 & $1215 \pm$ & & $-54 / 36$ & Perched lake 2 \\
\hline 34 & Dark mud & 5 & & & DON 4A-2-18 & Pollen-enriched extract & ULA-6137 & & & 8 & \\
\hline 35 & & 5 & & & & & & & & & \\
\hline 36 & & 5 & & -3 & & & & & & -521 & Perched \\
\hline 37 & Dark sandy mud & 4 & & -3.4 & DON 4A-3-7 & Pollen-enriched extract & 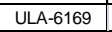 & $7490 \pm 20 \mathrm{BP}$ & 8336 & $-37 / 40$ & alluvial channel \\
\hline \multicolumn{12}{|c|}{ CORE Don-3 ( López-Cancelo, 2004), lake level $5 \mathrm{~m}$ amsl, lake depth $0 \mathrm{~m}$} \\
\hline 40 & & 5 & & -5.5 & DON3/1050 & Organic sediment & Ua-14390 & $1405 \pm 70 \mathrm{BP}$ & 1322 & $-141 / 95$ & Perched lake 1 \\
\hline & & & & & DON $3 / 1110$ & Organic sediment & Ua-14391 & $1795 \pm 75 \mathrm{BP}$ & & $-159 / 167$ & \\
\hline \multicolumn{12}{|c|}{ 2001), lake level ! } \\
\hline 42 & Organic silt & 7 & 420 & 0.8 & & organic sediment & & $530 \pm 30 \mathrm{BP}$ & 540 & & Distal alluvial \\
\hline \multicolumn{12}{|c|}{ CORE C-29 (Mosquera-Santé, 2001), sea depth $-34 \mathrm{~m}$ amsl } \\
\hline 43 & & 2 & 80 & -30.8 & & Foraminifera, carbonate & Ua-13208 & $2590 \pm 55 \mathrm{BP}$ & 2261 & $-149 / 140$ & Shoreface \\
\hline 44 & Sand & 1 & 390 & -33.08 & & Foraminifera, carbonate & Ua-12978 & $13645 \pm 160 \mathrm{BP}$ & 15900 & $-546 / 427$ & Sand barrier: aeolian \\
\hline
\end{tabular}

Table 1

This article is protected by copyright. All rights reserved. 


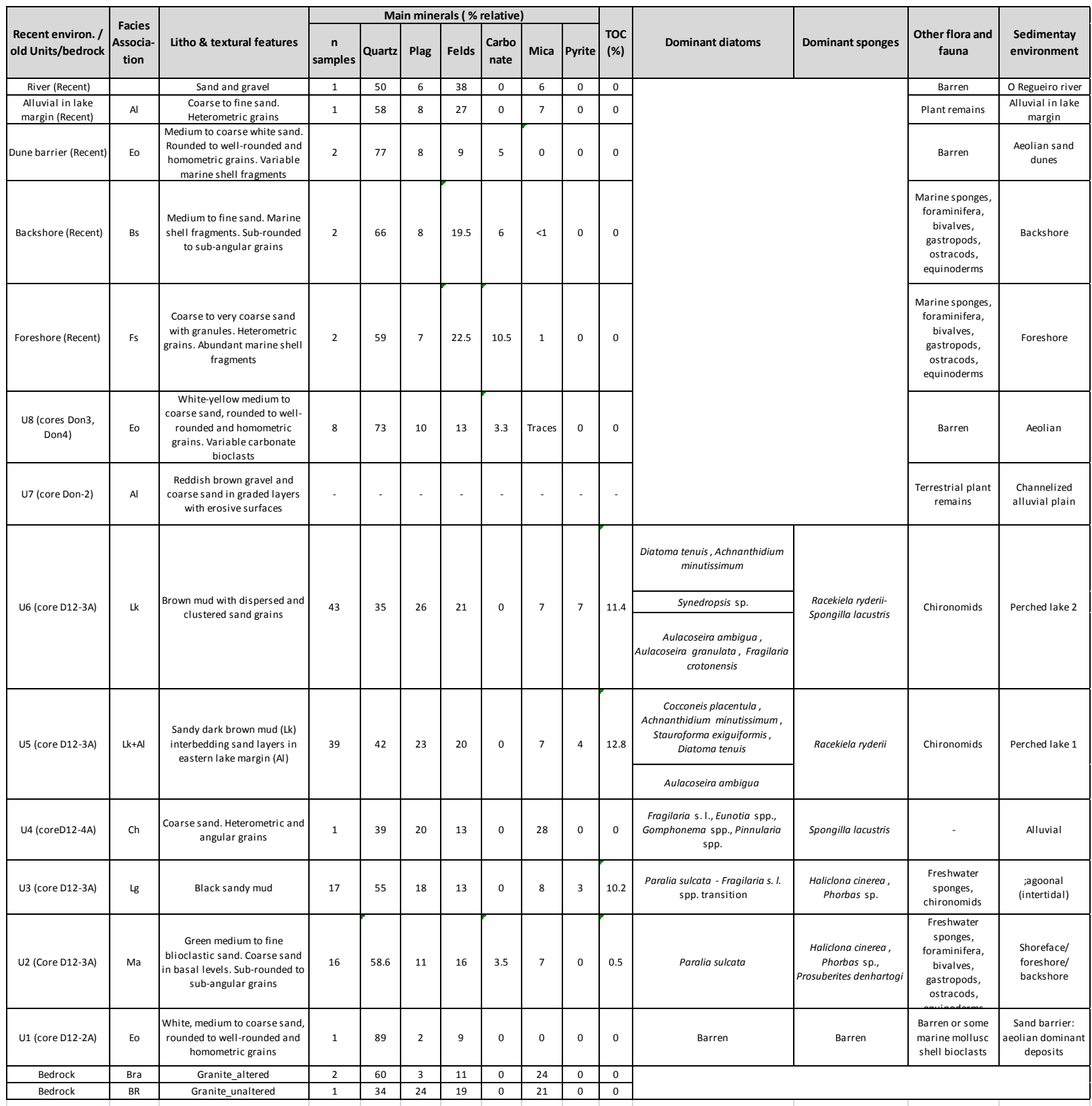

Table 2 

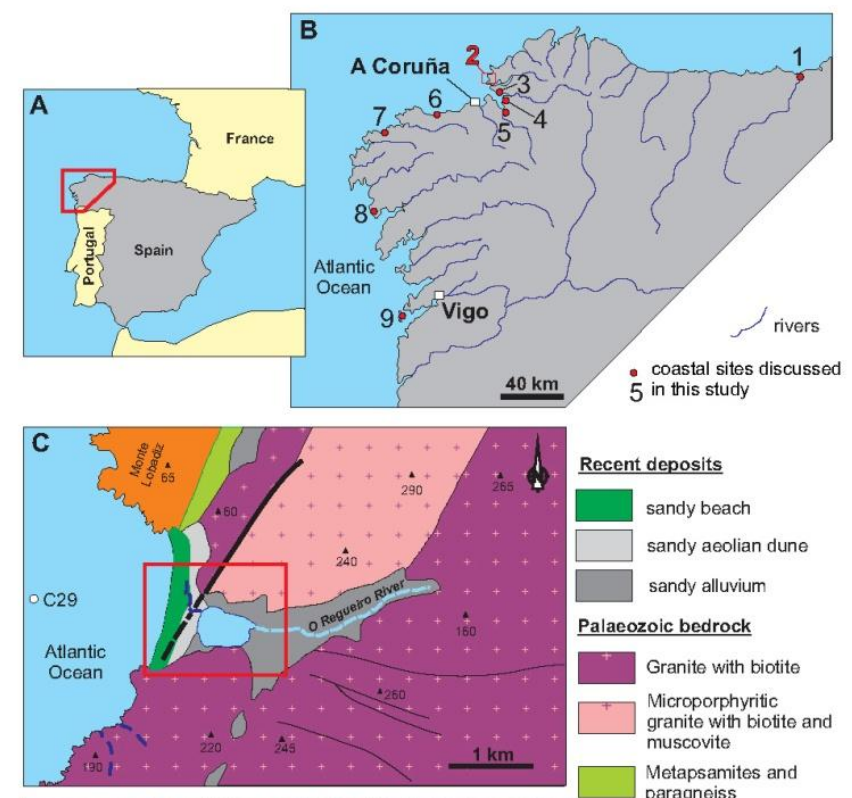

Recent deposits

$\square$ sandy beach
$\square$ sandy aeolian dune

sandy alluvium

Palaeozoic bedrock

Granite with biotite

Microporphyritic

granite with biotite and muscovite

Metapsamites and

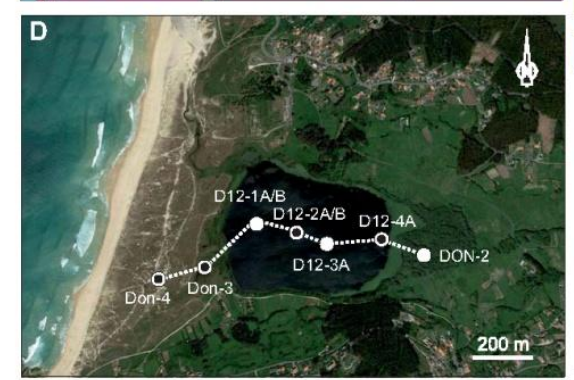

Porphyritic granite with

biotite and muscovite

fault affecting

s spot height

265 (elevation values: $\mathrm{m}$ )

cores not-reaching

bedrock

- cores reaching

bedrock

... cross section (Fig 3)

Fig. 1

This article is protected by copyright. All rights reserved. 


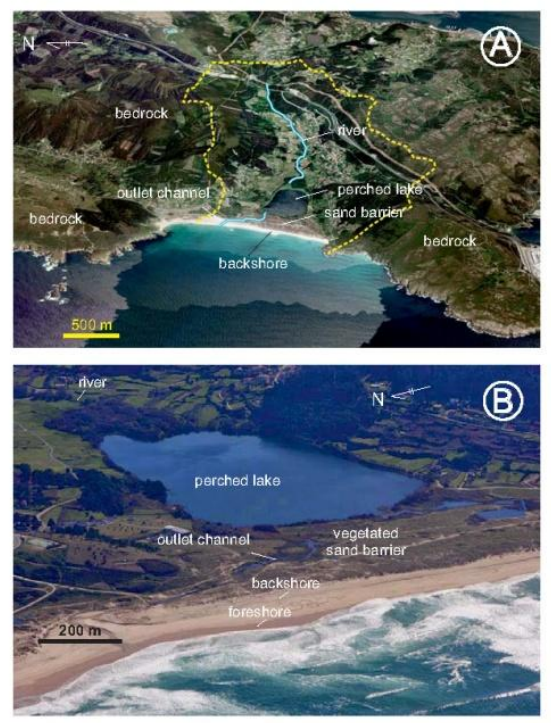

Fig. 2

This article is protected by copyright. All rights reserved. 


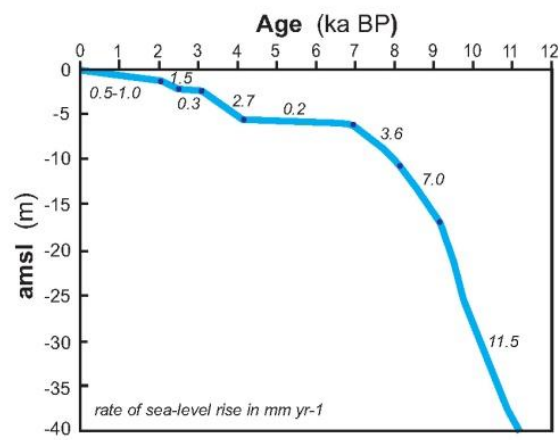

Fig. 3

This article is protected by copyright. All rights reserved. 


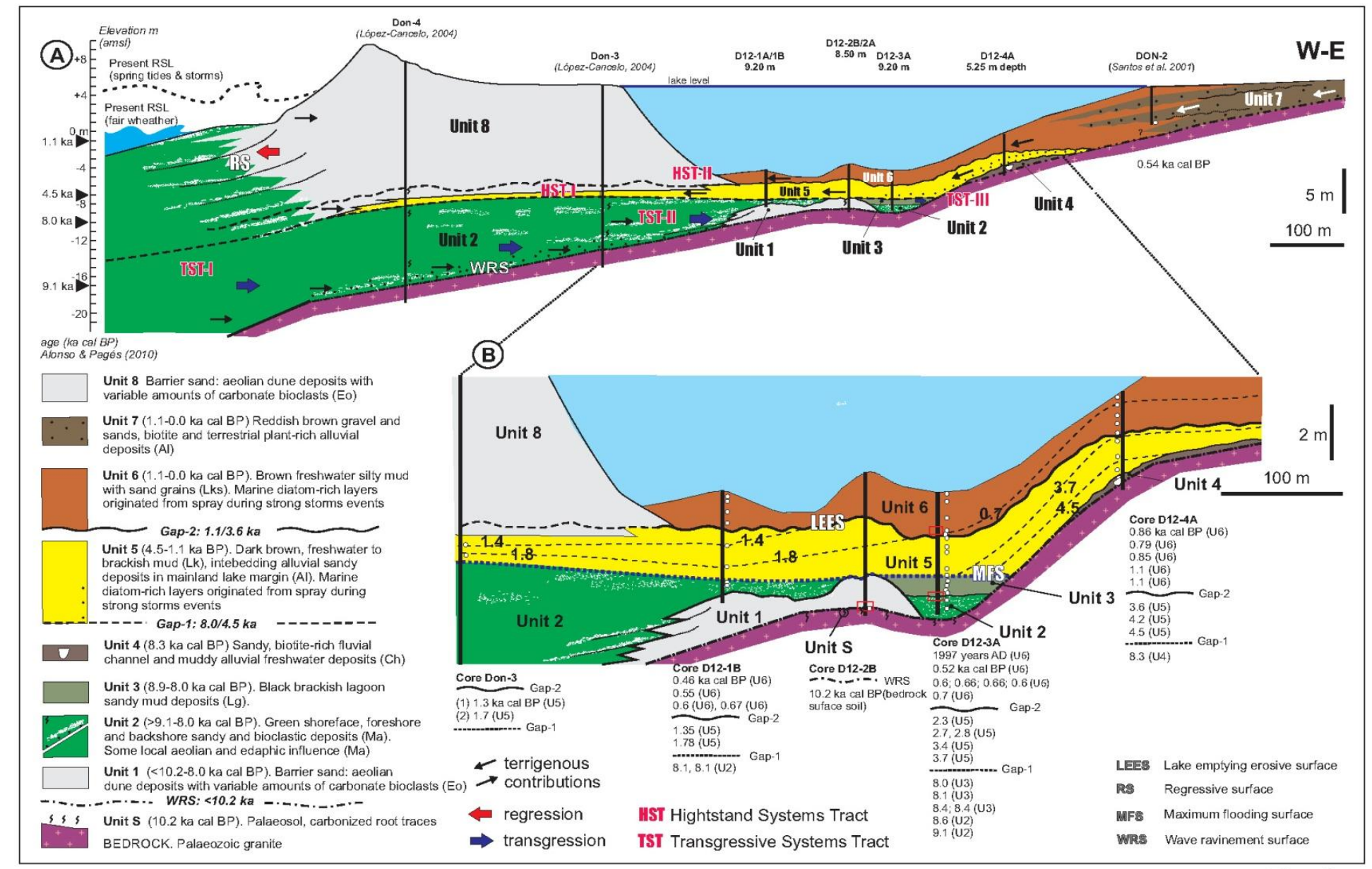

Fig. 4

This article is protected by copyright. All rights reserved. 


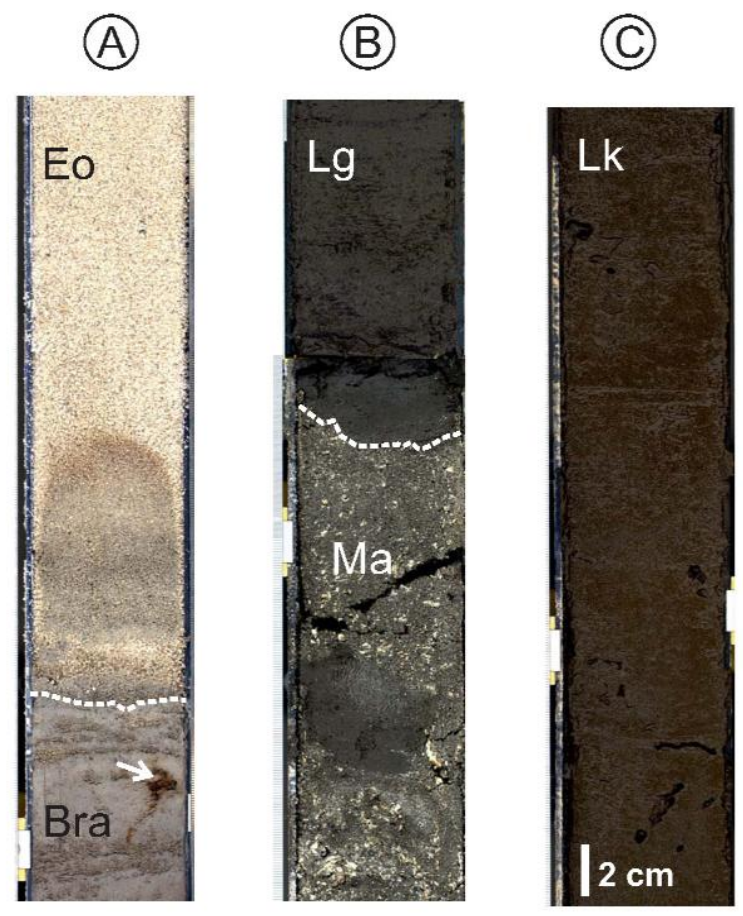

Fig. 5 


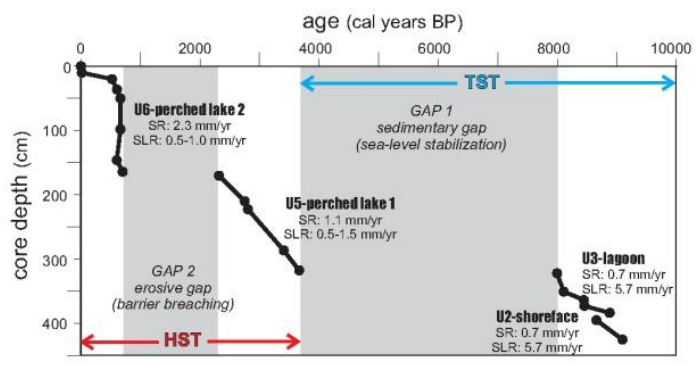

Fig. 6

This article is protected by copyright. All rights reserved. 


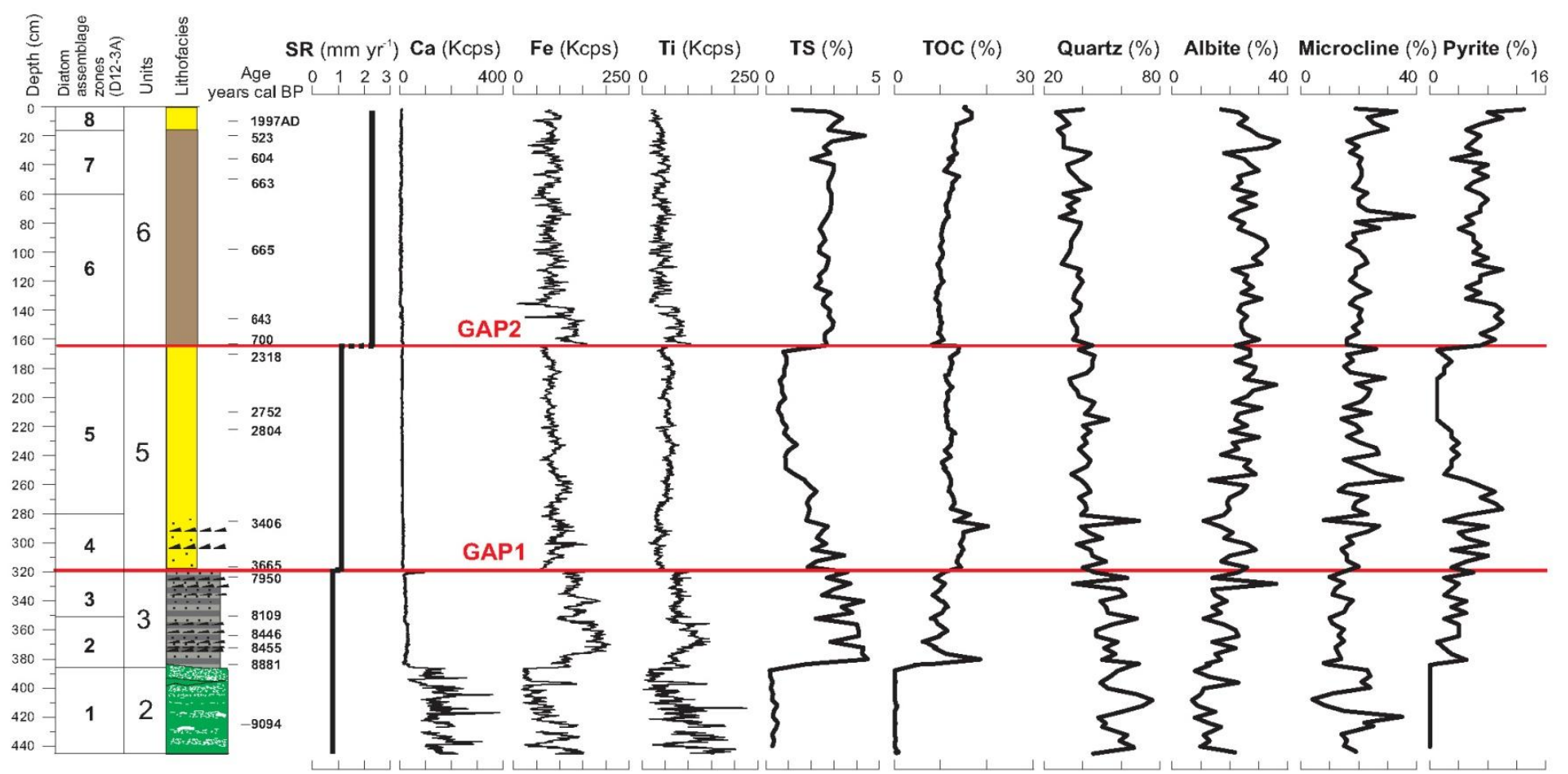

\section{FORESHORE-BACKSHORE DEPOSITS}

Fine to coarse green bioclastic sand. Shell fragments of marine mollusk (Facies Ma).

\section{LAGOON DEPOSITS}

Dark brown to black banded sandy mud (Facies Lg)

\section{PERCHED LAKE DEPOSITS}

Dark brown mud with sand grains (Facies Lks)

Dark brown mud (Facies Lk) ____ Thin sand layers (Facies Sd)

Fig. 7 


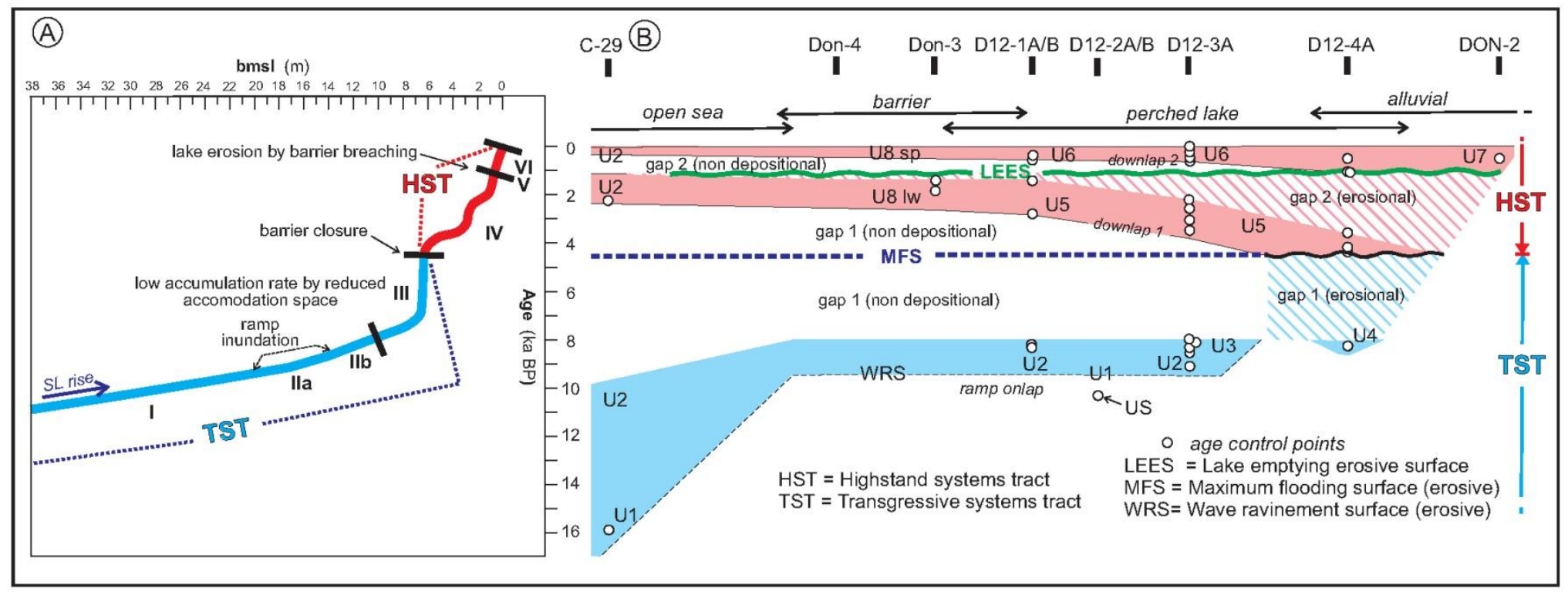

Fig. 8

This article is protected by copyright. All rights reserved. 


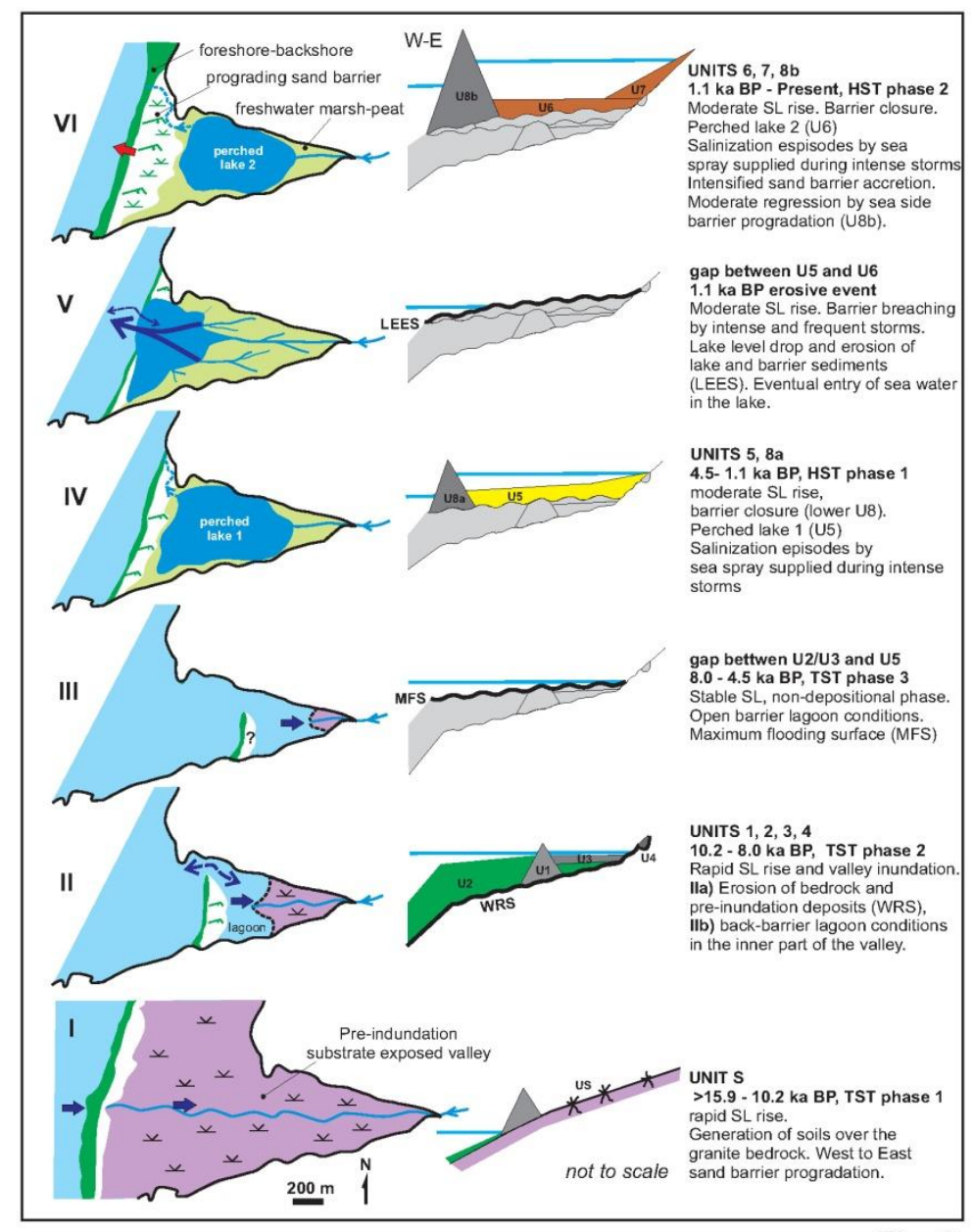

Fig. 9

This article is protected by copyright. All rights reserved. 


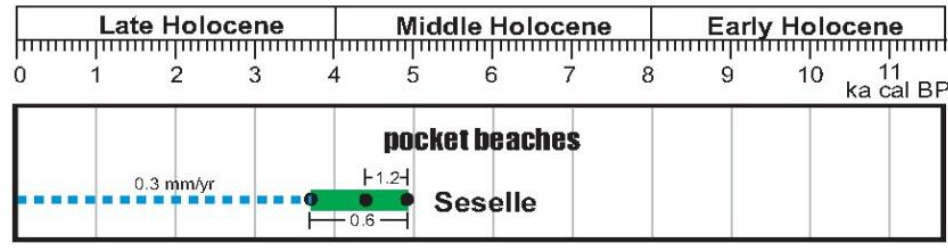
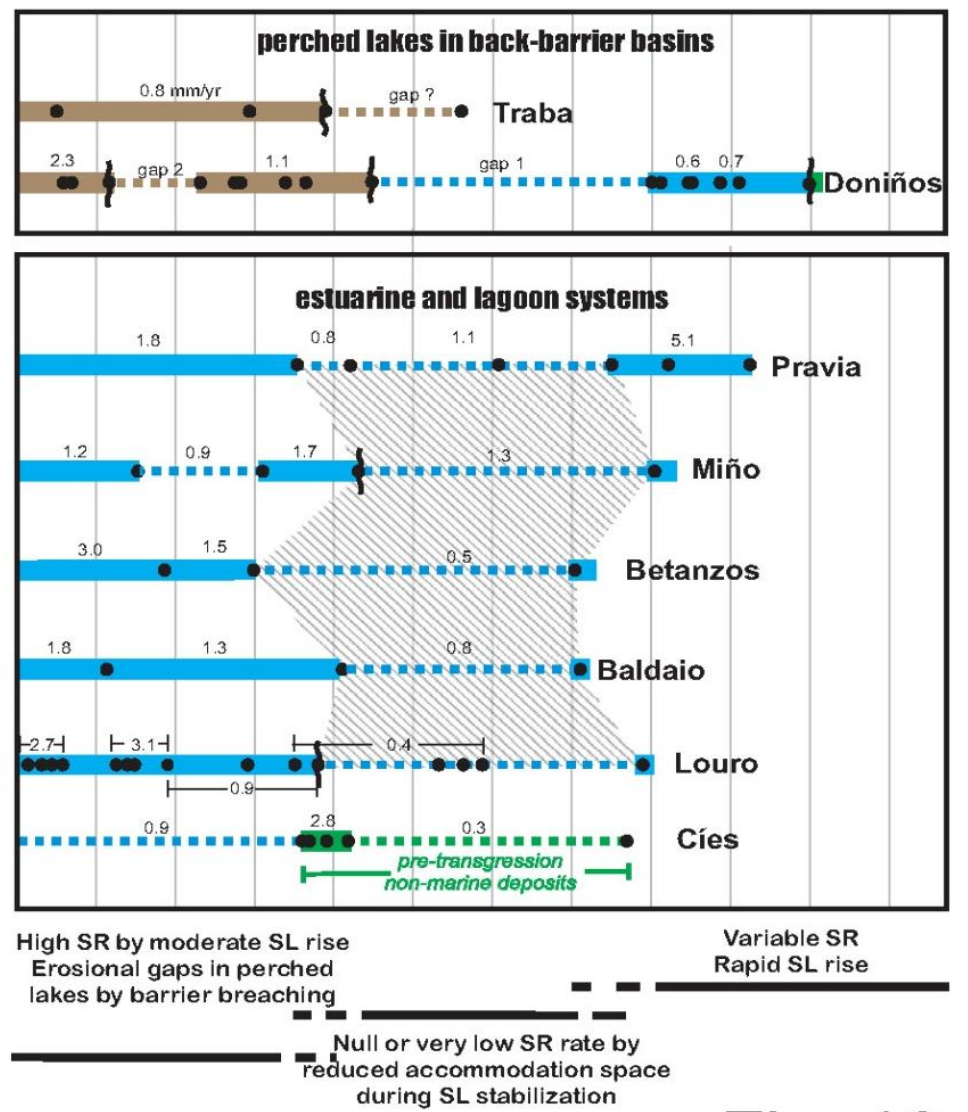

Fig. 10

This article is protected by copyright. All rights reserved. 